\title{
Semi-Urban Areas in Landscape Research: A Review
}

\author{
Steven J. Meeus \\ Department of Earth \& Environmental Sciences \\ K.U. Leuven \\ Celestijnenlaan 200E \\ 3001 Leuven, Belgium \\ email: steven.meeus@ees.kuleuven.be \\ http : //ees . kuleuven . be/staff/index . html ? sap $=43606$ \\ Hubert Gulinck \\ (same affiliation) \\ email: hubert.gulinck@ees.kuleuven.be \\ http://ees . kuleuven. be/staff/index.html?sap=7978

\section{Living Reviews in Landscape Research} \\ ISSN 1863-7329
}

Accepted on 17 November 2008

Published on 9 December 2008

\begin{abstract}
Urbanization is a well-known topic in sustainable development debates as it is known to have great impacts on landscape and environment. Low density, apparently random, scattered or fragmented and leap frogging forms of urban land use, not classified as core urban fabric (town, city, ... ) nor classified as real 'countryside' are studied in this paper. With a thorough literature study of more than 200 publications, a number of interesting conclusions about this important environmental and socio-economical phenomenon can be made. At first, it is generally described as either a type of land use or land use dynamic functioning as 'divide' between city and countryside (the urban fringe theory), or it is very often described as the dynamic and fast transformation of rural land into urban land (the sprawl approach). In some cases it forms its own 'landscape' and it is called the peri-urban or more correctly semi-urban area. Generally, there seems to be a lack of good definitions and frameworks, although it is studied often and in various scientific disciplines. Prominently, there is an always present dichotomy between rural and urban in all concepts, theories and definitions proposed.
\end{abstract}

Keywords: urban fringe, sprawl, semi-urban areas

This review is licensed under a Creative Commons Attribution-Non-Commercial-NoDerivs 3.0 Germany License. http://creativecommons .org/licenses/by-nc-nd/3.0/de/ 


\section{Imprint / Terms of Use}

Living Reviews in Landscape Research is a peer reviewed open access journal published by the Leibniz Centre for Agricultural Landscape Research (ZALF), Eberswalder Straße 84, 15374 Müncheberg, Germany. ISSN 1863-7329.

This review is licensed under a Creative Commons Attribution-Non-Commercial-NoDerivs 3.0 Germany License: http://creativecommons.org/licenses/by-nc-nd/3.0/de/

Because a Living Reviews article can evolve over time, we recommend to cite the article as follows:

Steven J. Meeus and Hubert Gulinck, "Semi-Urban Areas in Landscape Research: A Review", Living Rev. Landscape Res., 2, (2008), 3. [Online Article]: cited [<date $>$ ], http://www.livingreviews.org/lrlr-2008-3

The date given as $<$ date $>$ then uniquely identifies the version of the article you are referring to.

\section{Article Revisions}

Living Reviews supports two different ways to keep its articles up-to-date:

Fast-track revision A fast-track revision provides the author with the opportunity to add short notices of current research results, trends and developments, or important publications to the article. A fast-track revision is refereed by the responsible subject editor. If an article has undergone a fast-track revision, a summary of changes will be listed here.

Major update A major update will include substantial changes and additions and is subject to full external refereeing. It is published with a new publication number.

For detailed documentation of an article's evolution, please refer always to the history document of the article's online version at http://www. livingreviews.org/lrlr-2008-3. 


\section{Contents}

1 Introduction $\quad 5$

2 Reviewing semi-urban areas: methods and summary $\quad 7$

2.1 Methods used when reviewing . . . . . . . . . . . . . . . . . . . . 7

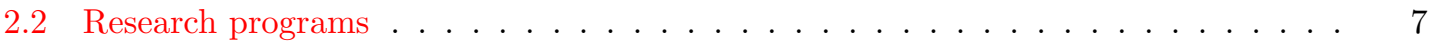

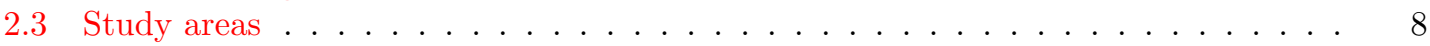

3 Definitions and theories $\quad 10$

3.1 The semi-urban condition . . . . . . . . . . . . . . . . . . 10

3.2 The "divide approach" . . . . . . . . . . . . . . . . . . . . 10

3.3 The "dynamic edge": the urban fringe . . . . . . . . . . . . . . . . . 11

3.4 The dynamics approach: urban sprawl . . . . . . . . . . . . . . . . . 12

3.5 Toward a more holistic approach: the semi- and peri-urban landscape . . . . . . . 13

3.6 Semi-urban areas in fast developing countries: Desakota . . . . . . . . . . . . . 15

3.7 Development models for fringe, sprawl, and semi-urban areas . . . . . . . . . . 15

4 Research issues concerning semi-urban landscapes $\quad 18$

4.1 Environmental impacts . . . . . . . . . . . . . . . . . . . . . . . 18

4.2 Detecting and measuring fringe, sprawl and semi-urban landscapes . . . . . . . . . 20

4.3 Sustainability and sprawl, semi-urban areas and urban fringes . . . . . . . . . . . 21

5 Conclusions $r 2$

6 Acknowledgements $\quad 24$

A Landscape research on semi-urban areas, conditions and dynamics: A literature summary

$\begin{array}{ll}\text { References } & 31\end{array}$

\section{List of Tables}

1 Publications using a 'dynamics' (sprawl) approach. . . . . . . . . . . . . . . 25

2 Publications using a 'landscape' approach (semi-urban areas). . . . . . . . . . . . 26

3 Publications mainly focussing on, or using, other concepts, theories and development models related to semi-urban areas. . . . . . . . . . . . . . . . . . 27

4 Publications with their focus on urban (and/or semi-urban) green structures). . . . 28

5 Publications focussing on methods and techniques to detect and or measure properties of variables related to semi-urban areas. . . . . . . . . . . . . . . . 29

6 Publications about general sustainability issues for semi-urban or related areas. . . 30 



\section{Introduction}

Since about the year 2000, more than half of the world's population lives in urban or highly urbanized areas (Swanson, 2007). The World Bank estimates that by 2030 the built-up area of industrialized countries will have expanded to some 500,000 square kilometers (Angel et al., 2005). So it can be emphasized that an important part of research concerning sustainable development should focus on these areas. From a traditional perspective, "urban areas" are generally interpreted as cities or towns with their specific urban form (Lynch, 1954), but numerous studies during the last decades suggest that urban areas have grown far beyond the edges of core city areas and agglomerations, this growth manifesting itself as urban sprawl, sometimes resulting in hybrid perior semi-urban landscapes. Suburbs and exurbs are rapidly expanding (Pickett and Cadenasso, 2008), with negative impacts on the environment (Baker et al., 2002; Doughty and Hammond, 2004; Hasse and Lathrop, 2003; Nuissl et al., 2009; Pauchard et al., 2006; Perry and Nawaz, 2008; Shaw et al., 1998; Syphard et al., 2007).

When systematically browsing scientific literature on subjects related to incompletely urbanized areas, three main research topics can be identified. The topic covered by the majority of research papers is about the environmental and ecological impacts of land transformations from rural to urban, or about the vicinity of urban development to natural resources. There is also much literature to be found on the economic (e.g. land value (Dwyer and Childs, 2004; Mori, 1998)) and social (e.g. segregation in the suburbs (Galster et al., 2001)) impacts, making the entire research topic around sprawl, the urban fringe (and its dynamics) and semi-urban areas a sustainable development issue in its full right. The effects of the urbanization processes or the effects of the presence of urban and semi-urban areas on the environment have been studied in numerous disciplines: urban planning (Cadieux, 2008; Frenkel, 2004b; Hümmeler, 1998), geography (Antrop, 2004; Bourne, 1996; Hagoort et al., 2002), sociology (Bialasiewicz, 2006; Bryant, 1995; Hite, 1998), ecology (Cornelis and Hermy, 2004; Gaston et al., 2005a; Shaw et al., 1998) and hydrology (Hasse and Lathrop, 2003; Perry and Nawaz, 2008). As a result of these studies, a rich but inconsistent vocabulary emerges to describe the region that is characterized by the expansion of urban fabric, the latter being the driving force of pressures to the environment. Overall, these papers focus on complexity, fragmentation, and heterogeneous land use (Carrión-Flores and Irwin, 2004; Gallent et al., 2004; Galster et al., 2001; Tacoli, 1998a,b). A second group of papers covers the analytical background of the landscape properties: research on indicators, scale issues, and method to measure sprawl, urban landscapes, and fringe dynamics. A third and smaller group of papers covers the actual descriptions, definitions, frameworks, concepts and policies around sprawl, urban fringes and semi-urban areas.

More often than not, the land use policy storylines remain within the classical dichotomy of urban versus rural areas: a result of separated traditions in science and in policies. Rural policies in the European Union for example, are still strongly linked to 'core' agricultural areas or to rural areas little transformed by urban and industrial development. Other sectors and activities in rural areas such as nature conservation are still relatively remote from urban conditions, both geographically and conceptually. Compared to rural discourses and policies, urban policies are based on completely different traditions and theories, with guiding disciplines such as architecture, civil engineering, urban planning, and transport science (Pickett and Cadenasso, 2008).

Because of disciplinary clefts between these different traditions and approaches, a standard definition of these semi-urban areas does not exist. Going more deeply into focal concepts of semi-urban areas, many authors also claim that there is a lack of a clear definition of closely linked phenomena: what exactly is sprawl, what is the urban fringe and what more generally are semi-urban landscapes (Adell, 1999; Antrop and Van Eetvelde, 2000; Fulton et al., 2001; Galster et al., 2001; Masuda and Garvin, 2008; Schuyler, 1986; Tacoli, 1998a; Theobald, 2001; Wolman et al., 2005; Yang and Hillier, 2007). With growing popularity of holistic, integrated (landscape) 
research (Antrop and Van Eetvelde, 2000; Musacchio and Wu, 2004), and with growing pressure on developing sustainability policies for complex environments, the need for a general framework for semi-urban areas, including definitions, measurement and interpretation tools, becomes inevitable.

The first specific objective of this paper is to make a synthesis of major descriptors of the semiurban condition. A second specific objective is to give a brief but comprehensive overview of the research topics related to semi-urban areas, in which the concepts from the first objective could be applied, or why they should be developed. In the first part of this paper, a short explanation about the methods, used to study the literature dealing in some way with semi-urban areas, is given, followed by a brief overview of some of the research programs, study topics and study regions often cited. The second part will then attempt to distill the main theories and concepts found in the literature and link them to actual research on semi-urban areas, ecological impacts, and sustainable land use planning.

Although it is difficult to create a clear-cut structure in a review with a such broad perspective, framework and somewhat theoretical and philosophical approach, the paper is organized in the following structure:

- The preceding text is the introduction: it gives the main background, the 'reason for reviewing' and the specific angles and viewpoints which form the baseline of the study.

- The next Section 2, 'Reviewing semi-urban areas', can be read as a "materials and methods" chapter. It explains the methods used conducting the review study. Since the "materials" in such a study mainly consist of (all kinds of) other publications, all of which can be found in the reference list, this chapter also gives a brief overview of a possible classification and summary (yet without interpretation) of the "where and what" of the studies, conducted in the literature that was consulted as sources for this study. In a later phase of the review, this information can be useful to give a - be it brief - practical state of the art of research on semi-urban areas and its parallel research topics.

- Sections 3 and 4, coping with definitions, theories, and research issues concerning semi-urban areas, should be read as the "results and discussion" part of the study. In these chapters, all information distilled during the reviewing process is identified, interpreted, linked to other information and explained. Because of the specific character (review) of the study, these sections, evidently, are much more than a sober summary of 'results', as is done when publishing field or lab experiments, for example. Both sections will already be more conclusive and interpretative and the reader may note that the 'line' between these sections and the last chapter, the conclusions, is not as "pure" as in other scientific papers.

- The last Section 5 contains the general conclusions, as a summary drawn from the discussion and results in the preceding chapters. 


\section{Reviewing semi-urban areas: methods and summary}

\subsection{Methods used when reviewing}

Searching literature started with a basic keyword based (web)search. On regular occasions, online literature resources were consulted for journal entries concerning the topics of the study. Among the online databases were the ISI Web of Science, Elsevier's ScienceDirect portal, Google Scholar, academic library websites, and publisher specific databases (e.g. Blackwell Synergy, Kluwer Academic).

The most frequently used keywords were "semi urban", "peri urban", "sprawl" and "fringe", in a list of more than 25 keywords. This keyword list was iteratively generated from the literature read: many publications containing the keyword "sprawl", also contained the keywords "sealed surface" and thus these latter were taken up in the list. From a certain point in reading, the rate to which new keywords entered the list dropped, from this moment on the assumption that the list could be seen as complete was made.

Many essential publications generated a new list of important references: this cited reference based search thus resulted in a list of almost 200 relevant publications. On several occasions, other publications of the same author, different than those listed in references of already selected relevant publications, were also consulted as they frequently cover the same topics.

During the literature study, specific attention was given to topics covering (1) former research or the research base of the study, (2) definitions, concepts, theories and nomenclatures and (3) study methods, especially sampling techniques. The discussion in this paper is primarily based on the findings from (2) and partly from those in (1).

\subsection{Research programs}

Interesting research programs on urban sprawl, semi-urban areas and the rural-urban fringe are conducted in landscape research across the world, though the biggest, interdisciplinary and international research projects on sprawl and semi-urban areas can be found in Europe, as research programs have been sponsored by the European Union. Certainly worth mentioning in this context is the MOLAND (Monitoring Land Use/Cover Dynamics) research program led by the Institute for Environment and Sustainability - Land Management and Natural Hazards Unit of the Directorate General Joint Research Centre, in cooperation with many other EU-based institutions, such as the European Environmental Agency (European Commission - DG JRC and Space Applications Institute) in Copenhagen (EEA, 2006) and Eurostat in Luxemburg, or the ESPON (European Spatial Planning Observation Network) 1.1.2. project, finished in 2005, investigating urban-rural relationships in Europe (ESPON, 2006). There are many other research programs induced by European Union research frameworks and followed up by academic institutions that are not part of the EU administration. Some examples of already finished projects include the SCATTER (Sprawling Cities And Transport - from Evaluation the Recommendations) research project (Gayda et al., 2005) in the EU 5th Research Framework, finished in 2004, and the RURBAN (Rural Areas under Urban Pressure) project at Wageningen University (Overbeek and Vader, 2003), also EU 5th Framework and finished in 2005.

At the moment, probably the largest running EU-financed research project on sprawl, semiurban areas and urban fringe land use is the EU 6th Framework-funded PLUREL (Peri-Urban Land Use Relationships) project. With a consortium of research institutions in 14 European countries and China, the project focuses on the challenges of urbanization and the very specific rural-urban regions, with the Leipzig Charter on Sustainable European Cities as background document (Leipzig Charter, 2007). Other interesting research programs are, for example, the "Peri-Urban Interface" program at the Development Planning Unit of the University College London (PUI), or the BUGS (Biodiversity in Urban Gardens) research program at the University of Sheffield. Although the 
latter does not contain any direct research on the general urban context issues discussed in this paper, the research projects in the BUGS program do investigate several ecological properties in gardens, being a form of urban land use that does not only exist in city centers, but also far outside the city limits. Much research conducted in the BUGS framework is discussed in the "Urban Domestic Gardens" paper series, for example, by Thompson et al. (2003); Gaston et al. (2005a); Smith et al. (2005).

In North America, many studies on sprawl, semi-urban areas and urban fringe dynamics are funded (and thus steered) by government agencies dealing with non-urban land use like the U.S. Department of Agriculture or the U.S.D.A. Forest Service. An interesting research program is the BES project (Baltimore Ecosystem Study) which started off as the Urban-to-Rural Ecology Gradient Project, run by the Institute for Ecosystem Studies in New York. Examples here are the work of McDonnell et al. (1997) and Pickett et al. (2004).

A large scale, interdisciplinary research program generating a considerable amount of literature on sprawl and urban fringes is the CAP LTER (Central Arizona - Phoenix Long-Term Ecological Research) framework of the Arizona State University in Phoenix, conducting multiple long-term studies on the environmental effects of an expanding metropolis in a desert ecosystem. Some examples of papers brought forth from this research project contain the work of Luck and Wu (2002); Baker et al. (2002); Jenerette et al. (2007).

\section{$2.3 \quad$ Study areas}

During the odyssey through literature, a list of the locations of case studies and examples used in the papers was created. It is self-evident that many of these locations are dictated by the research framework where the study, containing the locations mentioned, fits in. Some of these research frameworks were discussed in the previous Section 2.2.

In Northern America, Phoenix in Arizona (Baker et al., 2002; Cook, 2002; Gober and Burns, 2002; Jenerette et al., 2007; Luck and Wu, 2002; Musacchio and Wu, 2004), New York City (AlfsenNorodom et al., 2004; Bugliarello, 2004a; McDonnell et al., 1997; Plantinga and Miller, 2001), Madison in Wisconsin (McMillen, 1989; Weng, 2007), Chicago in Illinois (Felsenstein, 2002; McMillen, 1989), Atlanta in Georgia (Bourne, 1996; Gillies et al., 2003; Wolman et al., 2005) and Baltimore in Maryland (Musacchio and Wu, 2004; Wolman et al., 2005) are often used cities to study urban sprawl and related subjects. Statewide studies cover, for example, California (Atkinson and Oleson, 1996; Cablk and Minor, 2003; Syphard et al., 2007), Illinois (Deal and Schunk, 2004; Sullivan et al., 2004), or New Jersey (Hasse and Lathrop, 2003; Walmsley, 2006).

Although still not as much investigated on the sprawl, fringe, or semi-urban subject as European and Northern American urban regions, Eastern Asian study regions are becoming more and more important, evidently because of the very rapid urbanization that is happening in some southeastern countries and especially in China. Examples of papers using cities and regions in Asia include Bangkok (Madhavan et al., 2001; Yokohari et al., 2000), Bangalore (Sudhira et al., 2004), Shanghai (Zhang et al., 2004), or Singapore (Yang and Lay, 2004).

In Europe, frequently used study areas are the Leipzig region in Germany (Böhm, 1998; Haase and Nuissl, 2007; Hümmeler, 1998), Leeds (Freeman, 1999; Perry and Nawaz, 2008) and Sheffield (Gaston et al., 2005a; Smith et al., 2006; Thompson et al., 2005) in the United Kingdom and the Flanders region in Belgium (Antrop and Van Eetvelde, 2000; Casaux et al., 2007; Gulinck and Wagendorp, 2002; Hermy and Cornelis, 2000).

The Flanders study region, in particular, forms a specific type and good example study area in the sprawl/fringe/semi-urban area context. The northern part of Belgium is one of Europe's most densely populated areas with 443.3 inhabitants per square kilometer in 2003 (FOD Economie, 2008), contains some important European cities like Ghent, Antwerp and Brussels ${ }^{1}$, and still has an

\footnotetext{
${ }^{1}$ Though the city of Brussels in Belgium is administratively not part of the Flanders region, it is geographically
} 
important agricultural production. In contrast with other European countries like the Netherlands, the United Kingdom, or Germany, Belgium (and thus Flanders as well) had a very liberal spatial planning policy since the 1950s, which resulted in the fact that the majority of the countryside of Flanders has a somewhat urban character. Especially the central part of Flanders now can be described as a very hybrid matrix of countryside, containing a few big cities, some towns, many smaller settlements and this all connected with very dense infrastructure networks, not seldom accompanied by vast linear areas of ribbon-building. Hidden behind these built-up structures, a considerable acreage of agricultural and natural open space (as opposed to urban 'closed' space) is still present, be it highly fragmented. With these properties combined, the Flemish landscape outside the city limits in many cases resembles neither countryside, nor cityscape but in fact something 'in-between': large areas of Flanders can thus be seen as a good example of a 'semiurban area'. Flanders is not a unique case; there are other regions with apparently the same characteristics, for example the Lisbon province north of the city of Lisbon, Portugal, the Veneto province in Italy, the Département Nord in the North of France, or the Mediterranean coastal regions of France and Cataluña, Spain.

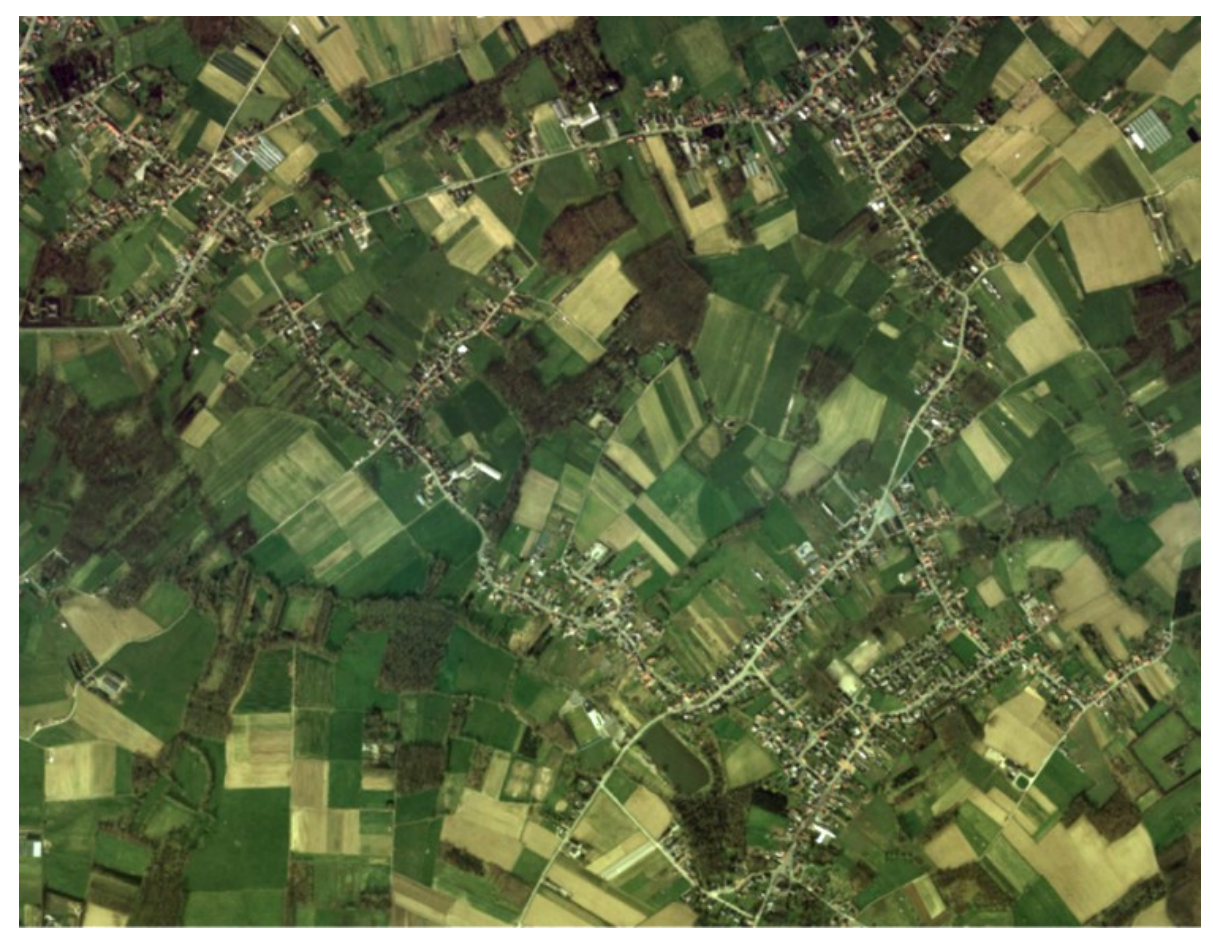

Figure 1: Ribbon-building in the Flemish countryside

seen 'surrounded' by Flanders and had thus great impact on this region when considering the urban related topics discussed in this paper. 


\section{Definitions and theories}

\subsection{The semi-urban condition}

Tacoli (1998a) gives a number of examples - ranging from Senegal to the Philippines over China to Europe - showing different definitions of "city", "countryside", and of areas that either are situated geographically "in between" city and countryside, or differ from rural and urban landscapes in configuration, functions, and other characteristics, so that they cannot be called city, nor countryside.

A large number of papers on urbanization and related topics starts from the viewpoint of the 'nearby city' as driving factor - hence most studies refer to urban geographic theories and typologies (Antrop, 2000b; Antrop and Van Eetvelde, 2000; Lewis and Brabec, 2005). In many cases, the semi-urban areas studied are in the vicinity and under influence of urban cores and thus referred to as "peri-urban" (Allen, 2003; Cavailhès et al., 2004; Tacoli, 1998a; Adell, 1999; Casaux et al., 2007).

In the literature, different categories explicating the "semi-urban" condition can be found, which can be divided into two groups. Firstly, there are descriptive categories, which primarily try to develop analytical frameworks under one of the following captions: the urban-rural divide, the fringe, sprawl, and semi-urban landscapes. The second group corresponds to development or strategic categories for sustainable development including garden cities, new urbanism, landscape urbanism, urban agriculture, neo-rurality, and ecopolis.

Only in rare cases, the phenomena are approached from a more explicit rural reference. Gonzalez-Abraham et al. (2007) write of "rural sprawl" (i.e. urban fabric 'sprawling' in a rural land use matrix) and Friedberger (2000) mentions the "rural fringe" being under pressure of urban expansion. When describing the metropolitan area of Phoenix, Arizona, Gober and Burns (2002) define an "outer rural zone" - thus incorporating this still mainly agricultural region inside a bigger, predominantly urban, context.

The inherent complexity of the semi-urban areas puts the traditional duality of rural vs. urban areas in question (Gulinck, 2004). To give it some analytical order, Gulinck suggests distinctions between sealed vs. unsealed, open vs. closed, urban and industrial functions vs. rural and natural. This problem is confirmed by Tacoli (1998b), who states that the high rates of failures of development strategies are often due to lack of recognition of the complexity of rural-urban interactions which involve spatial as well as sectoral dimensions.

\subsection{The "divide approach"}

The categorical divide between rural and urban is a practical response to clarity in land use policy and tenure. It is deeply embedded in culture, in science, and in planning. Strictly spoken, this divide concept is a denial of a semi-urban or semi-rural state, but it does reflect certain realities. First of all, it implies the possibility for a clear categorization of "urban" vs. "rural".

Local and regional government agencies tend to apply either an urban or a rural focus (Allen and Dávila, 2002) on their own definition of their districts. The categorization of districts as rural or urban is often set by thresholds of demographic density. Also, a combination of criteria may be used, including next to demographical numbers the share of agriculture, distance to urban centers, concentration of commercial and administrative activities, and others (Robinson, 1990).

Rural districts, on the other hand, are in most cases defined in an indirect way, as districts in which urban characteristics are absent or scarce (The Wye Group Handbook, 2007). In cases where more direct definitions are pronounced, they generally refer to traditional land use, rural communities and agriculture. Such pragmatic categorization may hide differences in perception within a single area: perceptions of rural and of urban character can vary between native rural people, new residents, tourists, and planners (Tilt et al., 2007).

Living Reviews in Landscape Research

http://www.livingreviews.org/lrlr-2008-3 
The use of criteria and thresholds to define "urban" and "rural" creates apparent clarity, but is at odds with the lack of a fundamental definition of what is precisely urban and what is rural (Countryside Agency Research Programme, 2002; Theobald, 2001). Since there are no unique indicators, nor quantitative thresholds with which to distinguish rural from urban areas, it is even more problematic to find sharp guidelines to demarcate semi-urban from urban respectively rural areas.

The urban-rural divide has become a misleading metaphor that oversimplifies and even distorts the realities (Leinfelder, 2007; Tacoli, 2003).

\subsection{The "dynamic edge": the urban fringe}

The word 'urban fringe' suggests a topological category, not a sharp divide or edge, but a border zone of an urban area. In further descriptions its dynamic nature - in terms of pressure from the urban area - is revealed as well. According to Hite (1998), the fringe is a frontier in space where the economic returns to land from new urban land uses are roughly equal to the returns from traditional land use. In this sense, the fringe is the losing edge of rurality, and steadily moving outward into the countryside.

The countryside at the farther end of this front can be called peri-urban. The urban fringe is characterized by relatively strong pressures for growth compared to more distant rural areas. Space, land use, social composition, and the economic bases of the different communities are strongly differentiated (Bryant, 1995). According to Hite (1998), the fringe is the ever continuing expression of global to local impacts on prices and of the relative costs of conflicting land uses and commodities. The potential for urban-rural win-win deals is bleak, unless vigorous counteraction in land use policy in implemented. Declining transport costs and communication costs in the general process of globalization are causing factors. Farmland is an important provider of open space which introduces an important pressure on farmers living in or in the vicinity of the fringe (Ryan and Hansel Walker, 2004). The U.S. Census Bureau defines urban(ized) areas as comprising of one or more urban cores (central places) and the adjacent densely settled surrounding territory, which is then called the fringe (Kline, 2000).

Urban fringes as a dynamic "border" zone have been studied often as part of a landscape or phenomenon. Seldom is the fringe itself, as a stand-alone geographical entity object of landscape study.

Examples of these studies are the morphological study of the fringe of Phoenix, Arizona by Gober and Burns (2002), or the study of the fringe areas of Chicago by McMillen (1989). Indirectly, the landscape ecological properties of fringe areas are also studied when using approaches with urban-rural gradients as methods. An often cited example here is the Phoenix urban landscape study of Luck and Wu (2002), which covers the entire metropolitan area of Phoenix, Arizona, using a gradient analysis approach, calculating specific landscape metrics to characterize and classify the area.

Next to the morphological properties of the fringe, more attention is given to the study of land use dynamics in fringes, as conversion from agricultural or natural land into urban land (Hite, 1998; Theobald, 2001), for example in Ohio (Carrión-Flores and Irwin, 2004), in Canada (Beauchesne and Bryant, 1999; Bryant, 1995) or Japan (Mori, 1998) or in the same sense, the multifunctionality of land use in the urban fringe, as for example described by Gallent et al. (2004) and Adell (1999), or by Cavailhès et al. (2004), who are calling the fringe "the belt outside the city limits occupied by both households and farmers".

In sociology and economics, the urban fringe can also be considered a well-studied area. Since real estate prices and urban expansion go hand in hand, numerous studies of the urban fringe deal with economic aspects. Well-known examples are Deal and Schunk (2004) who modeled effects of urbanization on land prices, or Libby and Sharp (2003) who introduce the concept of social capital 


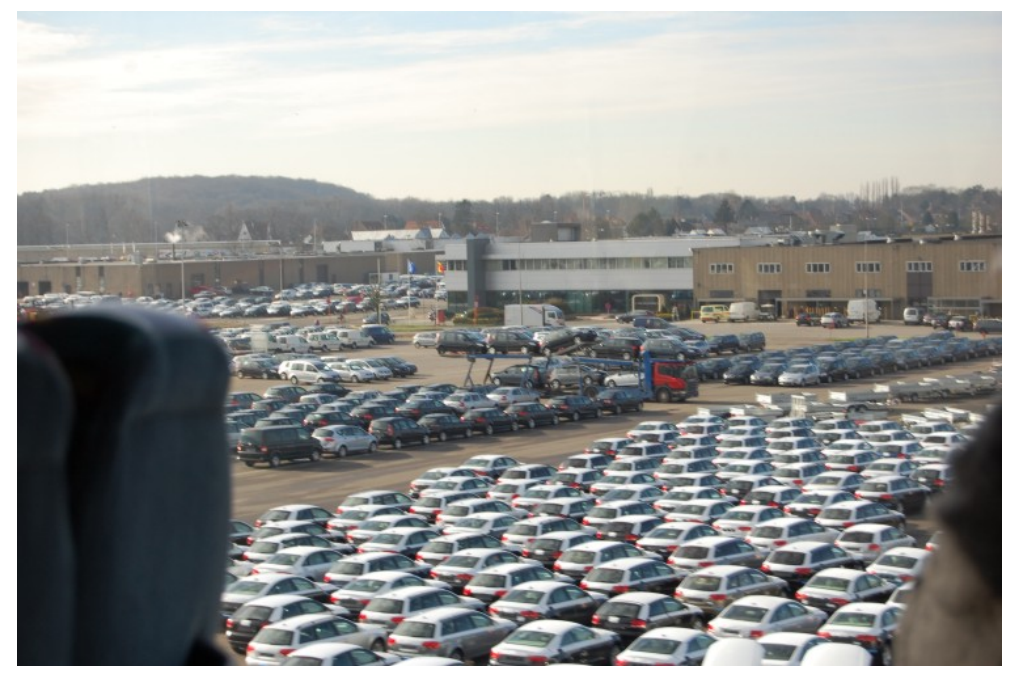

Figure 2: A typical form of urban fringe land use: retail and storage facilities in the countryside between Leuven and Brussels, Belgium.

as a socio-economic instrument in urban fringe regions. An example of econometric modeling in fringe areas, where the competition between residential and agricultural land use is explained using variables like distance to the nearest town or metropolitan area (Chicago in this case) can be found in the work by McMillen (1989).

\subsection{The dynamics approach: urban sprawl}

Sprawl is a term often used to describe perceived inefficiencies of development, including disproportionate growth of urban areas and excessive leapfrog development (Carrión-Flores and Irwin, 2004; Irwin and Bockstael, 2004). The European Environment Agency sees sprawl as the leading edge of urban growth (EEA, 2006). In general, most authors and researchers define sprawl as that kind of urban expansion where the rate of land consumption is higher than the increase in population density (Fulton et al., 2001; Wolman et al., 2005). Sprawl is an exurban land use change with a footprint exceeding the minimum required for the activity developed (Allen, 2006).

Kasanko and colleagues performed a study on 15 European cities and concluded that whereas cities in the south of Europe tend to become denser, most cities in northern and western Europe become more dispersed in the countryside: so the "fringe" phenomenon makes place for "sprawl" (Kasanko et al., 2006). Whereas a fringe still denotes a specific place, close to some core area, this is less the case for sprawl, which is rather a dynamic process than a geographical area. Sprawl not necessarily radiates from a center, but is a phenomenon that is less dependent on distance constraints. However, the European Environmental Agency still defines sprawl as a "physical pattern of low-density expansion of urban areas, under market conditions, mainly into the surrounding agricultural areas" (EEA, 2006). According to the same source, this results in a patchy, scattered, strung out, discontinuous and leapfrogged landscape.

Sprawl is not a random phenomenon: much urban development is closely related to infrastructure networks (Ewing et al., 2000; Schrijnen, 2000), whilst Felsenstein (2002) investigated the relationship of sprawl with high-tech agglomerations around bigger cities. McDonnell and Pickett (1990) define sprawl as an increase in human habitation, with increased per capita energy consumption and an extensive modification of the landscape creating a system that does not depend principally on local resources to persist. Urban and suburban sprawl is one of many inter-linked

Living Reviews in Landscape Research

http://www. livingreviews.org/lrlr-2008-3 
components of the movement of people across the landscape (Dwyer and Childs, 2004). Sprawl stays an elusive term: according to Fulton et al. (2001), it could mean auto-oriented suburban development, or low density residential subdivisions on the metropolitan fringe, or even any kind of suburban growth style, whether driven by population increase or not. The latter definition is regularly used in popular press.

It is difficult to apply one single definition to a problem. Fulton et al. (2001) state that there is no unique 'sprawl' problem in the United States. Sprawl is often confused with 'general suburbanization' (Torrens and Alberti, 2000), without clear empirical foundation. Lewis and Brabec (2005) define sprawling urbanization as a fifth landform next to the four urban types defined by Lynch and Bacon: nuclear, linear, stellar and constellation (Lynch, 1954; Bacon, 1974). Galster et al. (2001) define sprawl as a pattern of land use in an urban area that exhibits a combination of eight distinct dimensions of land use in low levels: density, continuity, concentration, clustering, centrality, nuclearity, mixed use and proximity.

An indication of the difficult quest for identity of diffuse expansion of urban development is the large vocabulary in different languages: next to words like sprawl itself, network city, periphery, fragmented urbanization, in Italian città diffusa and città frattale (the fractal city) (Batty and Longley, 1997) are used, in Dutch we find nevelstad ("nevel" meaning mist or haze), rasterstad (grid city), and tapijtmetropool ("tapijt" is carpet) (Urban Policy Project, 2003; Leinfelder, 2007), in French hyperville (megapolis in English) (Bourne, 1996) and ville émergente (Dubois-Taine and Chalas, 1997).

In the older literature about the expansion of urban cores, three main theories can be found: the concentric zone theory first developed by Burgess (1925), followed by the sector model theory of Hoyt (1939), concluding with the multiple nuclei theory first discussed by Harris and Ullman (1945). Some of the more recent city model theories include the catastrophe theory or the chaos theory of Wilson $(1976,1981)$, the dissipative structure model, the theory of self-organization or fractal models (Batty and Longley, 1987). Most of these concepts imply the reference of the classical, concentrated urban condition and describe some form of new urban conditions at low spatial density. In metropolitan areas or where larger cities are located close to each other as is the case in many regions in Europe (Hagoort et al., 2002), in the Bay Area in California (Schrijnen, 2000), in the Boston-Washington megapolis or in Japan (Mori, 1998), the cities and their surrounding perior semi-urban areas merge into large city regions, where residential areas, retail, services, industries, leisure centers and parks form a network of functional nodes connected by transport infrastructure: urban landscapes often referred to as conurbation (Countryside Agency Research Programme, 2002; EEA, 2006), superburbs (Bourne, 1996), grid cities (Schrijnen, 2000) or constellation regions (Lynch, 1954).

\subsection{Toward a more holistic approach: the semi- and peri-urban land- scape}

Many authors claim two important consequences of sprawl, the urbanizing landscapes and fringe land use dynamics: first, landscape dynamics like sprawl cause such changes that the resulting land use is hard to be classified as either rural or urban land use. Land use becomes blurred (Dwyer and Childs, 2004). Secondly, because of the dynamic character of the fringe areas, they become so scattered, broad or detached from the city core, that defining them as the border or fringe between city and countryside becomes ambiguous (Tacoli, 1998a) or with a "fuzzy boundary" (Yang and Hillier, 2007).

Cavailhès et al. (2004) recognizes a sprawled area beyond the city limits and suburbs, but no more real countryside: a belt outside the city limits occupied by both households and farmers. As a result of sprawl, a contiguous territory with specific characteristics develops (Kline, 2000) . This is the rationale to lift both "fringe" and "sprawl" toward the level of "landscape". Instead of 
looking at some badly analyzable spatial and functional chaos, some organizational and functional logic is searched for. Few authors, however, will explicitly mention the rural-urban transition zone as a specific landscape. Moreover, landscapes strongly affected by urbanization do not fit the traditional schemes of landscape definition and analysis, which are strongly rooted in historical reference frameworks (traditional rural landscapes, natural landscapes) or in theories and practice of landscape design.

In a first group of articles, semi-urban landscapes are seen through a strong urban bias. Allen and Dávila (2002) define a peri-urban interface: a mosaic of agricultural and urban ecosystems, subject to rapid change with a large social mix and with clearly measurable distinctive features (Allen, 2003). Another definition of the area 'between' countryside and city is what Irwin and Bockstael (2004) call the exurban areas beyond suburbia on the rural-urban divide. Bourne (1996) describes an evolution towards "exurbia", a semi-urban landscape beyond suburbia: suburbs become edge cities and they become "superburbs", a phenomenon frequently studied in the United States (Bourne, 1996; Bugliarello, 2004a; Felsenstein, 2002; Holden and Turner, 1997; Theobald, 2001). Bourne also states that there is no clear border between suburbia and this exurbia that contains edge cities and semi-agricultural, semi-urban landscapes. Yang and Lay (2004) see these landscapes under urbanization pressures as "nurtured landscapes", literally fed by the cities which they enclose as peri-urban area. In densely populated areas with extensive networks of cities and town, the semi-urban landscape itself is enclosed by the city fabric, and thus "nurtured" by multiple sources. Wolman et al. (2005) propose the concept of the extended urban areas, based on housing density and commuting patterns.

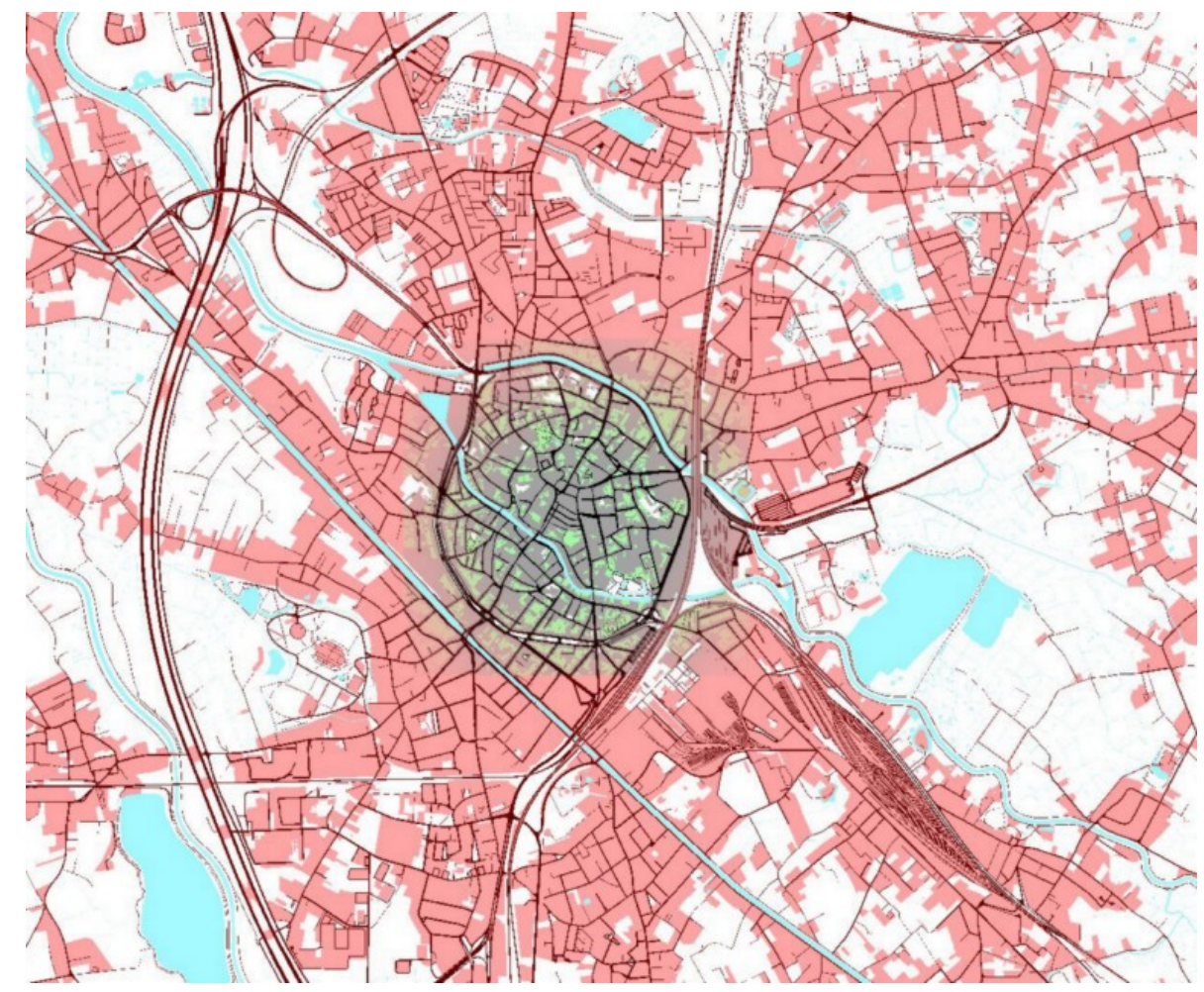

Figure 3: Urban sprawl (pink) creating a semi-urban area around Mechelen, Flanders region, Belgium.

In contrast with the former paragraphs, some authors partly reject the dependency-from-cities vision. According to Adell (1999), peri-urban zones are dynamic, both spatially and structurally,

Living Reviews in Landscape Research

http://www. livingreviews.org/lrlr-2008-3 
and form distinctive areas of agricultural and non-agricultural activity. Alfsen-Norodom defines the entire area around metropolitan areas as a separate "biosphere" - a concept to see a landscape with dense and less dense built-up areas and generally a hybrid land use as a entirely "new form of (dynamic) landscape", with its own biotopes, ecosystems and landscape dynamics (Alfsen-Norodom, 2004; Alfsen-Norodom et al., 2004). A typical "biosphere" related variable, carrying capacity can be useful as variable, to measure the semi-urban area, which can be seen as a heterogeneous mosaic of natural, production and agricultural ecosystems (Allen, 2003). Also Antrop and Van Eetvelde (2000) define the urban fringe as a landscape and not just a transition between an urban and a rural landscape. These 'new' landscapes are created by a functional heterogeneity and are much more complex in reality than many city or landscape models may show. Typical city models are not sufficient (Antrop, 2004).

Some theoretical support to develop a diagnostic framework for semi-urban landscapes can be sought in the analysis of its functional system. In urban fringes, a number of fluxes meet (Tacoli, 1998a, 2003): urban 'entities' (people, systems, industry, waste, products, culture, ...) enter these areas and are substituted for agricultural systems, products, even people. In a way, these semiurban areas function as a transfer area between urban and rural systems. Because of this, they are hybrid landscapes with both rural and urban properties, but also attract their own, specific kind of 'semi-urban' entities, such as 'urban agriculture' (Beauchesne and Bryant, 1999). This can be considered a rather optimistic viewpoint, stressing added value to and specific properties of the urban-rural mix.

\subsection{Semi-urban areas in fast developing countries: Desakota}

The Desakota concept deserves to be mentioned here: where traditional theories relate the rapid growth of cities in third world countries to fast depopulation of the countryside, in Southeast Asian regions another process is defined: the rural population, living within the hinterlands of large (rapidly industrializing) cities, is spontaneously transforming their rural lifestyles into urban ones without leaving their rural environments. So, in this approach, cities are not really expanding but the neighboring countryside is transforming 'itself' into a specific kind of semi-urban fabric (Adell, 1999; Heikkila et al., 2003; McGee, 1991; Xie et al., 2005; Yokohari et al., 2000).

\subsection{Development models for fringe, sprawl, and semi-urban areas}

From the early 19th century industrial towns, urban planning became the official and most adequate tool for the organization of urban fabric in and around towns and cities. The younger the urban planning theories, the more attention they pay to concepts such as sustainable development, landscape conservation, and urban ecology. In the following paragraphs, a brief overview of development theories is given. Some of these concepts or theories are specifically developed for the urban planning in semi-urban areas or are developed as an answer to fringe problems and sprawl. Other theories are more general urban planning theories, which however can be applied to those areas that are the subject of this paper. The main difference between these 'specific' theories and the 'general' theories is the basis where they were generated from: the specific theories are often developed as an answer to a specific problem (e.g. sprawl), while general theories involve a whole list of goals.

Rural planning principles were not often found in the literature, when using the review method as described earlier. Tilt et al. (2007) did study the perception of the rural character in areas subjected to sprawl and compared them with the perception of "pure" rural areas. Tress and Tress (2003) state that when planning urban expansion or other forms of urban driven development in the countryside, all stakeholders or people affected by this should be included in developing the plans. Like Tilt and co-workers, they also use visual materials in this transdisciplinary approach. 
Allen and Dávila promote the idea that semi-urban planning and urban planning should be the same discipline, especially in urban fringe areas (Allen, 2003; Allen and Dávila, 2002).

Maybe the oldest answer for sustainable semi-urban and peri-urban areas was the Garden City Movement, founded by Howard in 1898 (Lee and Ahn, 2003). The central idea is to create a cluster of communities or suburbs, all surrounded by greenbelts and planned with a balanced area for industry, agriculture, services. Hundred years later, the Garden City Movement also formed a base for the urban design movement New Urbanism. An interesting comparison between both movements can be found in the study of two cities, Kentlands and Radburn, by Lee and Ahn (2003). Yokohari et al. (2000) and colleagues applied the greenbelt idea from the Garden City concept on Asian mega-cities.

New Urbanism is a (architectural) design movement that specifically focuses on the improvement of the initial chaotic, inefficient and 'ugly' layout design of the suburban and exurban landscapes (Bourne, 1996; Katz, 1993). It is a movement 'against' sprawl, with a main goal being the preservation of open space (Talen, 2005; Congress for the New Urbanism, 1996): bringing order and coherence to the growing 'Edge Cities' on the urban fringe, by introducing (walkable) multifunctional and integrated urban areas on different scales (from town to neighborhood), always with a strongly integrated open space system (Walmsley, 2006). New Urbanism as a tool against sprawl is illustrated in a study by Skaburskis (2006) in Toronto, Canada.

Partly parallel to the New Urbanism approach, partly as a continuation and refinement of these theories, Landscape Urbanism is a modern design theory that proposes an alternative to sprawl inducing planning processes. Landscape Urbanism places the landscape (on or in which urbanization occurs) central as a model for urbanism and as a model for process as opposed to common planning, design, and architectural theories and policies (Allen, 2001; Hackworth, 2005; Shannon, 2004; Waldheim, 2006).

Urban ecology is an interdisciplinary science, where any urban system with its main components - human activity and artificial land cover, in conflict or competition with natural land cover - is studied as a 'natural system' with its own specific ecology (Breuste et al., 1998; Collins et al., 2000). These theories go back to the basic Ecopolis concept of Tjallingii (Pearce, 2006; Tjallingii, 1995), or the Ecocity builders (Register, 2002; Rees, 1999). It is a model for sustainable city planning, including urban agriculture, which measures avoiding sprawl or mitigating sprawl effects, avoidance of urban heat islands, and other ideas.

New forms of agriculture adapted to urban and semi-urban conditions are getting more and more attention (Jarosz, 2008). Urban and peri-urban agriculture, as (geographically) opposed to large-scale, intense, and traditional "rural" agriculture, is an example of modern agriculture (Tacoli, 1998b, 2003). It is a reply to a growing demand for short food chains, organic farming and high quality agricultural goods supply. Because of phenomena like sprawl, agricultural land in the vicinity of the urban fringes or in semi-urban areas is highly fragmented with, relative to traditional farms, small plot sizes and a small production in absolute figures. These farms, however, form an ideal multifunctional land use, not only for food production (be it smaller and less economically efficient in some cases), but for production of specific regional products, organic farming, agri- and eco-tourism (Beauchesne and Bryant, 1999; Bryant, 1995; Countryside Agency Research Programme, 2002).

The core of the concept of neo-rurality is to consider values, services, and functions linked to the unsealed soil beyond being a mere component of an urban or rural environment, and which are being managed and sustained by specific compartments of society. Distance to urban components is not a criterion. The concept is useful but not exclusive to semi-urban areas (Gulinck, 2004). Land-bound urban agriculture is an example of a neo-rural function, as is the acknowledgement of unsealed soil for water retention or microclimate regulation.

Smart growth is a recent planning concept now becoming popular in the United States as a framework to dam sprawl and work on sustainable city development. Although it is based on

Living Reviews in Landscape Research

http://www. livingreviews.org/lrlr-2008-3 
urbanistic principles and so primarily focused on the human-dominated environment, it incorporates elements from various other planning frameworks for sustainable (urban) development such as anti-sprawl measures, greenbelts, rural development near urban fringes and multifunctional land use (Burchell et al., 2000; Daniels and Lapping, 2005; Danielsen et al., 1999; Duany and Talen, 2002; Irwin and Bockstael, 2004; Walmsley, 2006). 


\section{Research issues concerning semi-urban landscapes}

When summarizing the (research) backgrounds of the publications analysed for this study, there are three main 'research issues' that always return, in most cases even in relationship to each other. The first - and most general - research topic which can focus on semi-urban landscapes, is the construction, study, or lack of a sustainability framework for this specific land cover. Very narrowly related to this topic, because it is inherent to the sustainability story, are the research topics concerned with the environmental impacts of, and inside, semi-urban areas. To study these latter two issues, there is obviously a need for methods, tools and technical knowledge to measure and detect or identify semi-urban areas, fringes, and sprawl dynamics and its properties - these research topics being the third often encountered issue.

\subsection{Environmental impacts}

Land transformations associated with urban expansion can significantly affect biodiversity, energy flows, biochemical cycles, climate conditions, hydrology, soil properties at local, regional and even larger scales (Baker et al., 2002; Breuste et al., 1998; Sukkop and Hejny, 1990).

Urban sprawl is often seen as a key sustainability problem (Davis and Schaub, 2005; Frenkel, 2004b; Galster et al., 2001; Hasse and Lathrop, 2003; McDonnell et al., 1997; Schrijnen, 2000). Sprawl causes fragmentation of open spaces with well-known consequences like habitat loss, landscape degradation, etc. (Alberti, 2005; Alig et al., 2004; Antrop, 2004; EEA, 2006; Gardner et al., 1993; Gonzalez-Abraham et al., 2007; Gulinck and Wagendorp, 2002; McKinney, 2002; Nuissl et al., 2009; Savard et al., 2000; Tischendorf and Fahrig, 2000).

Next to the fragmentation, sprawl also "consumes" land: natural and agricultural land is transformed, sometimes at high speeds, into "artificial" land covers, like residential, industrial or service areas. Not only does this result in a general decrease in agricultural and natural land, due to the competition with these types of land cover it chances their socio-economic properties, with a standard example the simplest of all indicators, the price of land (EEA, 2006; Felsenstein, 2002; Frenkel, 2004a; Kahn, 2000; Mori, 1998; Plantinga and Miller, 2001; Ryan and Hansel Walker, 2004).

Sprawl is characterized by auto-centered, low density communities that consume large amounts of open space per capita (Davis and Schaub, 2005; Fulton et al., 2001) and energy because of longer transport distances (Calthorpe and Fulton, 2001; Ewing et al., 2000; Gonzalez-Abraham et al., 2007; Muñiz and Galindo, 2005).

Sprawl is known to be the major cause of visual degradation in already densely populated areas in, for example, Southeastern Asia (Madhavan et al., 2001), California (Atkinson and Oleson, 1996; Fulton et al., 2001) or Northwestern Europe (Antrop and Van Eetvelde, 2000; EEA, 2006; Hagoort et al., 2002; Holden and Turner, 1997). Another negative effect of the existence of semi-urban areas, especially in more arid climates like the Californian or Australian deserts, is the increased fire risk (Syphard et al., 2007).

Other examples of ecological impacts of sprawl, semi-urban areas, or fringe dynamics are climate impacts. McDonnell et al. (1997) also studied ecosystem temperatures along a rural-urban gradient, Jenerette et al. (2007) proved regional relationships between surface temperature and vegetation in urbanizing ecosystems, Baker et al. (2002) studied this for the Phoenix metropolitan area in Arizona and Saaroni et al. (2000) studied the heat island effect in Tel-Aviv, Israel.

The bulk part of artificial land cover is impervious or at least only partly permeable. An increase in urban fabric automatically means a - sometimes dramatic - increase in area of impervious surface (Foley et al., 2005; Stone Jr, 2004), having impacts on all kinds of hydrological properties, like runoff and polluent infiltration (Bronstert et al., 2002; Carlson and Arthur, 2000; Haase and Nuissl, 2007; Niehoff et al., 2002; Pauleit and Duhme, 2000; Perry and Nawaz, 2008; Pickett et al., 2001;

Living Reviews in Landscape Research

http://www. livingreviews.org/lrlr-2008-3 


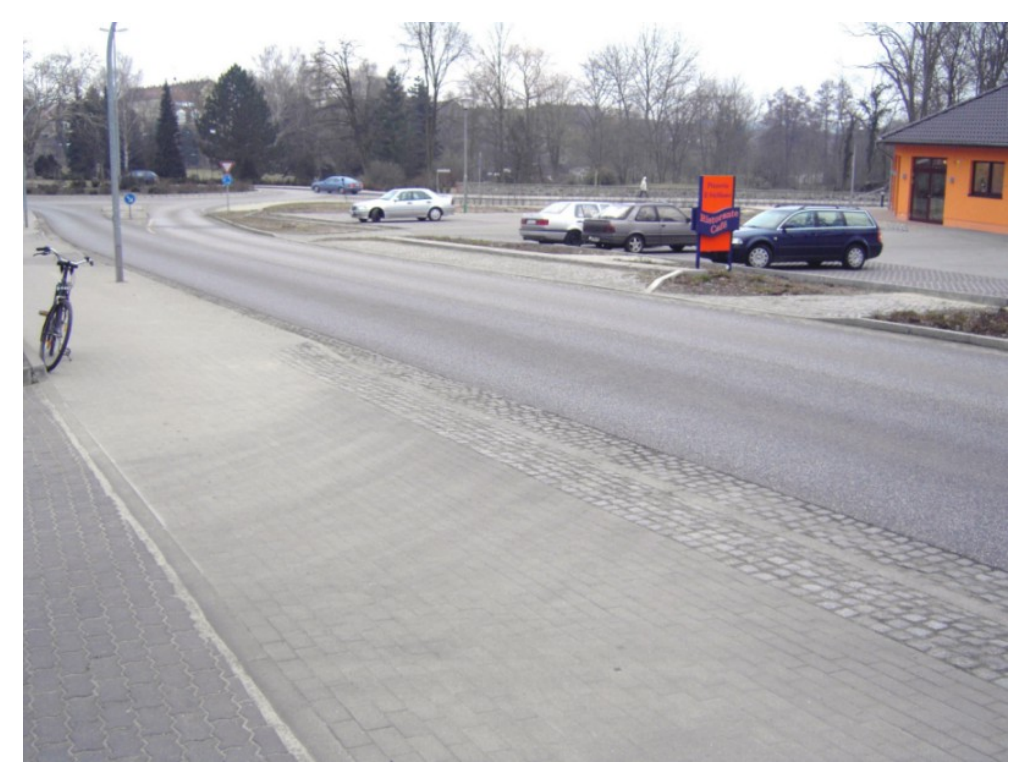

Figure 4: Urban sprawl is accompanied by an increase in impervious surfaces with well-known environmental impacts.

Ziegler et al., 2004). Measuring surface sealing is an important issue when studying flood control and urban hydrology (Jennings and Jarnagin, 2002; Jennings et al., 2004). It is no surprise that the evolution of sprawl and semi-urban areas is narrowly followed by hydrologists (Gillies et al., 2003; Hall, 1989; Hoggan, 1989; Pauleit et al., 2005; Shaw, 1988; Zheng and Baetz, 1999).

A meanwhile very common way to calculate the impact of any form of human activity, thus including urban expansion like sprawl or the existence of semi-urban areas, is by calculating the ecological footprint (Bugliarello, 2004b; Muñiz and Galindo, 2005). Rees (1992) calculated the footprint of sprawl in a valley in Canada, Alfsen-Norodom (2004) did similar experiments for the New York metropolitan area, Doughty and Hammond (2004) did a thorough footprint analysis for the Bath region, U.K.

Another big impact of sprawl, semi-urban areas and fringe expansion and dynamics that needs to be mentioned is what can be called the 'garden' effect. Urban sprawl in most cases means a large growth in residential area (compared with the increase of industrial or other artificial, anthropogenic land cover). In developed countries, an increase in residential area, mostly also means an increase in garden area, since the majority of the 'growing' residential area, in the fringe, sprawling, in the semi-urban area, is low density housing, accompanied by gardens and on top of that public or semi-public green areas like road verges, parks, golf courses and other forms of green recreation sites (Colding, 2007; Loram et al., 2007; Poole, 1993; Smith et al., 2005). While, on the one hand, this increase in green biomass could be an improvement when considering it as pure 'biomass' and carbon dioxide storage (Bjerke et al., 2006; McDonnell et al., 1997; Platt, 2004; Yokohari et al., 2000), this is not always the case when discussing biodiversity. Gardens and parks possess large amounts of exotic plant species and thus not only introduce non-native species, but also increase competition between exotic and native plant species, in some cases resulting in a decrease of native flora as well as native fauna ecologically linked to those native species (Alberti, 2005; Gallent et al., 2004; McKinney, 2002; Niemelä, 1999; Pauchard et al., 2006; Savard et al., 2000; Theobald, 2004; Vogtländer et al., 2004). Extensive research has been done on biodiversity in and around gardens in the Urban Domestic Gardens research in, for example, the Sheffield region, U.K. (Gaston et al., 2005a,b; Loram et al., 2007; Smith et al., 2005, 2006; Thompson et al., 2003, 


\section{5, 2004).}

The important role of public green in the urban ecology debate for sustainable cities can be found in studies of biodiversity in parks (Cornelis and Hermy, 2004; Hermy and Cornelis, 2000) and their role as buffers, social important locations, and landscape connectors (Angel et al., 2005; Bjerke et al., 2006; Countryside Agency Research Programme, 2002; Chiesura, 2004; Niemelä, 1999).

\subsection{Detecting and measuring fringe, sprawl and semi-urban landscapes}

Definitions or descriptions given to specific forms of land use or its dynamics, define the way it is measured. For example, large studies are conducted to measure sprawl and its impacts. Examples of studies only measuring the physical and landscape ecological properties of sprawl are done, for example, by Malpezzi and $\mathrm{Guo}^{2}$ or Torrens and Alberti (2000), and the study of sprawl as a process by Wolman et al. (2005). Studies measuring the impacts of sprawl, semi-urban landscapes, and land-use interactions on the urban fringes form a long list, of which examples are discussed further on in this paper.

A specific method of studying urban fringe systems and sprawl, which is related to urban cores, is gradient analysis. Good examples of this method are the studies of McDonnell (McDonnell and Pickett, 1990; McDonnell et al., 1997), the detailed rural-urban gradient analysis of the area around Phoenix by Luck and Wu (2002), and the GIS based gradient analysis of the urban landscape and sprawl dynamics in China, in Shanghai (Zhang et al., 2004) or Guangzhou (Yu and Ng, 2007). Other rural-urban gradient studies cover ecological indicators (McKinney, 2002), residential building patterns (Weng, 2007), land use properties like vegetation type (Zhao et al., 2007), sealed surfaces (Jennings et al., 2004), or building densities (Longley and Mesev, 2002).

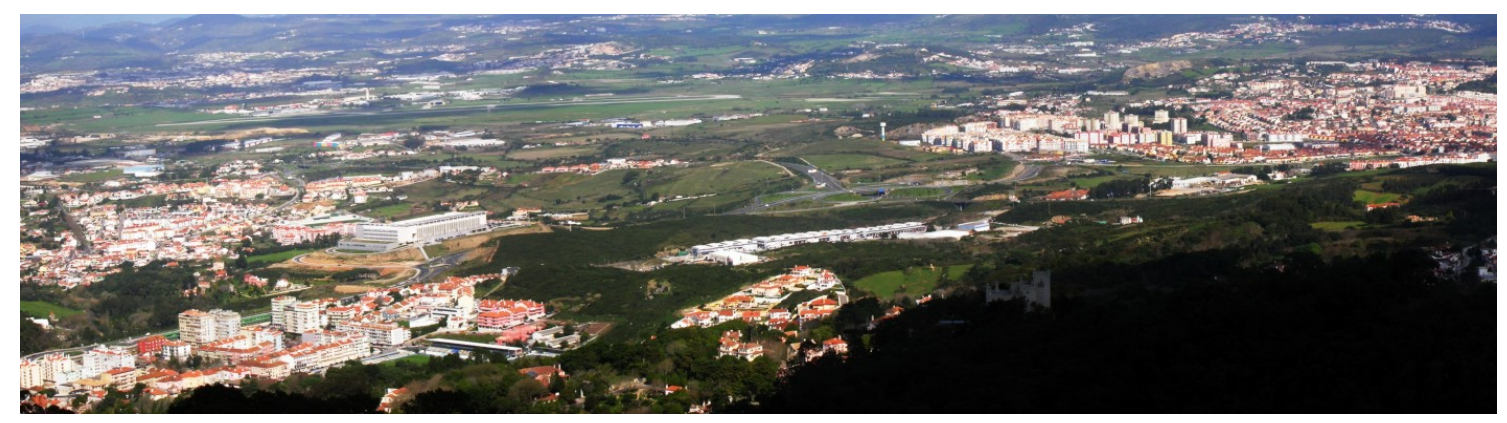

Figure 5: Panorama of a semi-urban landscape seen from the hills of Sintra, north of Lisbon, Portugal.

Multiple authors emphasize the importance of choosing the right scale properties when studying sprawl phenomena, the rural-urban fringe, and semi-urban areas. Especially when measuring physical geographical properties like landscape metrics as fractal dimension, diversity indices or patch densities, properties as resolution, study area extent, and classification type have great influence on the results of the measurements (Cain et al., 1997; Hasse and Lathrop, 2003; Lam and Quattrochi, 1992; O’Neill et al., 1996; Saura, 2004; Wu, 2004).

Because of the heterogeneity of semi-urban land use and the hybrid, intricate and apparently 'unorganized' structure, working with high resolution data for high levels of detail is often recommended both for monitoring (Cablk and Minor, 2003; Chen and Stow, 2003; Herold et al., 2002), as for modeling (Pontius Jr et al., 2004). Spectral unmixing may provide some solution for the

\footnotetext{
${ }^{2}$ Malpezzi, S. and Guo, W.K.: "Measuring Sprawl: Atlernative measures of urban form in U.S. metropolitan areas" - unpublished paper from the Centre of Urban Land Economics, University of Wisconsin, Madison, USA.
}

Living Reviews in Landscape Research

http://www. livingreviews.org/lrlr-2008-3 
detail enhancement of low resolution spatial data (Raymaekers et al., 2005; Wu and Murray, 2003), however, extra and more detailed ground data is needed for verification (Jensen and Cowen, 1999).

\subsection{Sustainability and sprawl, semi-urban areas and urban fringes}

Theobald (2001) recommends researchers to recognize the ubiquity of exurban areas and better incorporation of fine scale patterns of land use beyond the urban fringe. The literature concerning sustainability and semi-urban areas reveals three groups. The first group relates different demands for land use to each other, not only at local level (direct competition for land and incompatibility of land uses) but also at global level (footprinting). The second group rather focuses on the local to global environmental impacts other than related to land take. The third group assumes a more positive stance in focusing on the benefits and ecological opportunities of the green component in (semi-)urban areas.

Many authors suggest planning concepts or tools, derived form these theories, for sustainable urban planning. Tools like the "urban structural unit" principle (Böhm, 1998), conurbation measures (Countryside Agency Research Programme, 2002) or planning concpepts like the Biosphere project (Alfsen-Norodom, 2004; Alfsen-Norodom et al., 2004), multifunctional agriculture (Casaux et al., 2007) or neo-rurality (Gulinck, 2004) are certainly worth mentioning and open interesting paths to a general improvement of landscapes consisting of a rural-urban matrix.

Pickett et al. (2004) proposes the concept of "cities of resilience", with a deep link between urban design and ecology, a parallel can be found in the "nurtured landscape" view of Yang and Lay (2004).

Good examples of decision support strategies as a tool for sustainable urban planning of semiurban areas include sprawl measures, master plans, neighborhood development tools, hierarchical processes for evaluation, growth management, and the implementation of green structures as an instrument and are abundant in the literature (Banai, 2005; Cadieux, 2008; Daniels and Lapping, 2005; Hümmeler, 1998; Jensen et al., 2000; Yli-Viikari et al., 2007). 


\section{Conclusions}

After this review-like study, a result of reading more than 200 publications, reports, proceedings and other papers, the following conclusions can be distilled.

It is generally agreed that half of the world's population lives in a landscape that can be classified as 'urban'. However, this does not mean that half of the world lives in cities. In large parts of the world, especially in developed countries or rapidly developing countries, these urban landscapes differ in density, spatial configuration and land use properties from 'urban cores', cities or towns. The increasing number of papers on the broad theme of intake of rural and natural area by urbanization processes and of the resulting state of a semi-urbanized conditions and its impacts on society, the economy, and the environment, leaves no doubt that this subject is soliciting due interest. The major conclusion of this review, however, is the apparent persistent lack of consistency in definitions, vocabulary, and above all, a diagnostic grammar.

The two most frequently used concepts to describe the semi-urban state are "fringe" and "sprawl". Although the semantics are somewhat blurred, both terms point to fundamentally different spatial expressions of urban expansion. Fringe implies an outer zone of urban expansion that outwardly radiates from core urban areas. Sprawl much more implies the emergence of spatially distributed urban conditions, much less dependent of core areas.

Research on sprawl, fringes, and semi-urban areas can is conducted in ecological, social as well as economical sciences; it leaves no doubt that the whole sprawl-fringe-semi-urban area concourse is a full-issue sustainability topic. In this paper, only the ecological dimension of the sustainable development is the primary focus. When browsing literature about sprawl, urban fringes, and semi-urban landscape, ecological impacts are most commonly studied, since these forms of land cover dynamics can have great impacts on biomass availability, biodiversity, soil quality, hydrology, landscape structure and conservation, habitat fragmentation and many other topics. A second topic, often found linked with sprawl and semi-urban areas are technical issues, frequently dealing with data properties like scale effects. The need for high resolution and very detailed data to study semi-urban areas and sprawl effects is repeatedly emphasized.

A broad range of development strategies and concepts exists, almost all of them have as goal sustainable (urban) planning and propose, for example, measures to restrict sprawl: New Urbanism and Landscape Urbanism as architectural theories, Smart Growth as an example of sustainable policy concept.

One would expect an equilibrated approach to semi-urban areas from two groups of disciplines: the "urban disciplines" and the "rural disciplines". To the contrary, however, there is a very strong bias of urbanistic approaches. This can be explained by the fact that the most obvious and active process in these areas is of strong urban nature, the rural and natural area being the "loosing aspect". Whereas the phenomena of sprawl and the fringe can be fully acknowledged as specific forms of urban development, the residual rural characteristics in the semi-urban area seem to be much less attractive as focal issues for rural development. So, from international to local level, the definition of rurality commences with the exclusion of land areas above a threshold of urban development. Urbanistic theories and practice are much less tempted to exclude thinly built-up areas from their fields of research and application.

Exceptions to this exclusion behavior of rural research and application can be found in the upcoming theme of urban agriculture, but here again, the key characteristic of this agriculture is urban, and the emphasis in this field is to turn farming as part and parcel of urban, not rural development. This apparently persistent allocating of open space functions to either the rural or the urban side of the semi-urban continuum appears to be difficult to be countered. The concept of neo-rurality, although the name suggests positioning at the rural side, is meant to develop concepts for sustainable use of unbuilt spaces irrespective of their geographical position, close to or far away from urban fabric.

Living Reviews in Landscape Research

http://www. livingreviews.org/lrlr-2008-3 
Much less frequently, compared to sprawl and fringe, half urbanized areas are being categorized as a specific type of landscape. This can be explained in different ways. First of all, the term of landscape implies some recognizable order or pattern in terms of ecological functioning, land use, visual quality, historic development or characteristics in general sense. The typical heterogeneity of spatial, environmental and use conditions in half urbanized areas make these hard to fit into the landscape analytical schemes. However, the landscape concept - with its branches in landscape ecology, landscape design, etc. - is a potential field for developing sustainability development principles, but here again the urban-rural divide is lurking, for instance in the discipline of landscape urbanism, in which landscape principles are fully integrated in urban development.

Although plenty of research is committed to topics such as sprawl, urban fringes, and semiurban areas, several authors point to the lack of a clear definition of what sprawl, the urban fringe, and a semi-urban area is.

This paper illustrates that sprawl, urban fringe dynamics, and semi-urban area issues are 'hot topics' in actual research concerning sustainable development. It also illustrates the great diversity of concepts, theories, definitions (and the lack of them) and approaches. For an important part, this can be justified by the fact that every scientific discipline starts from its own basis and thus develops its own approach and theory around the topics here discussed. On the other hand, this is in contradiction with actual popular concepts of integrated, inter- and multidisciplinary approaches, certainly in landscape research (Antrop, 2000a; Pickett et al., 2001; Tress et al., 2006; Wu and Hobbs, 2002). Where there is already a fair amount of research done on the impacts of urbanizing and already (semi-) urbanized landscapes and the application of existing planning concepts as remedies, the construction of a general, multi-applicable framework for landscapes subjected to urban sprawl, the urban fringe, or semi-urban landscapes is still scarcely out of the egg.

\section{Towards a general definiton for semi-urban areas}

An important next step in the aftermath of this study, could be the formulation of a new, generalizing definition of semi-urban areas, although one of the main conclusions of this paper is that finding a "general denition" is very difficult, maybe even impossible, due to the various different approaches on the subject, the different frameworks, needs, etcetera. As an illustration, a possible definition - or at least start of - is provided in the next paragraphs. It has to be noted that this should be understood as a beginning and that the definition is not (yet) tested on a sufficient number of case study areas and is highly dependent on the (landscape ecological) background of this study.

In a landscape ecological context, a landscape can be identified as a semi-urban area,

- when its land cover consists of a sufficient high degree, but not exclusively, of artificial land use with a mainly urban land cover that can be classified as sealed surface (transport infrastructure, buildings and other built-up urban fabric) and

- when its land cover also consists of a sufficient degree, but not exclusively, of green structures, possibly entirely or partly of artificial nature, that may accompany built-up structures or have a specific social or ecological function in an urban context, like parks, road verges, gardens and

- when it can be clearly measured that the land use is in some way dynamic, either because of a pressure from factors coming from other surrounding landscapes (population growth or movement, for example) or a pressure created by the land use itself (for example, more intense road infrastructure development because of a higher degree of commuting) and

- when it can also be proven, possibly by using a reference landscape, that the area of study is neither "pure" urban core (village, city, town), nor "pure" agricultural" land, nor "pure" 
natural area. In principle, if the triangular relationship between (a), (b) and (c) is clearly a fact, condition (d) is unnecessary.

\section{Acknowledgements}

The authors would like to thank Valerie Dewaelheyns and Kirsten Bomans for the many discussions and viewpoints about semi-urban areas and the two anonymous reviewers for their very useful comments. 


\section{A Landscape research on semi-urban areas, conditions and dynamics: A literature summary}

Table 1: Publications using a 'dynamics' (sprawl) approach.

\begin{tabular}{|c|c|c|c|}
\hline Authors & Year & Keywords & Study Area \\
\hline Allen & 2006 & Editorial / Sprawl definition & No specific study area \\
\hline Atkinson et al. & 1996 & Urban sprawl in economic context & California, U.S.A. \\
\hline Calthorpe & 2001 & $\begin{array}{l}\text { Regional cities / Edge cities / Urban fringe- } \\
\text { sprawl }\end{array}$ & No specific study area \\
\hline $\begin{array}{l}\text { Carrion-Flores et } \\
\text { al. }\end{array}$ & 2004 & Sprawl / Suburbia / pattern analysis / Fragstats & Ohio, U.S.A. \\
\hline Croissant & 2004 & Urban fringe / parcel boundaries / LULC & Indiana, U.S.A. \\
\hline David et al. & 2005 & Sprawl / metrics / impervious surfaces & $\begin{array}{l}\text { Pacific Coast Region, } \\
\text { U.S.A. }\end{array}$ \\
\hline Dwyer et al. & 2004 & $\begin{array}{l}\text { Sprawl / blurring of distinctions between urban } \\
\text { and rural }\end{array}$ & No specific study area \\
\hline EEA & 2006 & Sprawl / indicators / study for Europe & Europe \\
\hline Ewing et al. & 2000 & Transportation impacts / sprawl / PCA & $\begin{array}{l}\text { Metropolitan areas, } \\
\text { U.S.A. }\end{array}$ \\
\hline Frenkel & 2004 & Sprawl models / Planning principles & Israel \\
\hline Fulton et al. & 2001 & Sprawl / auto-oriented / population density & U.S.A. \\
\hline Gillies et al. & 2003 & $\begin{array}{l}\text { Impervious surfaces / Aquatic fauna (mussels) / } \\
\text { growth }\end{array}$ & Atlanta, U.S.A. \\
\hline $\begin{array}{l}\text { Gonzales-Abraham } \\
\text { et al. }\end{array}$ & 2007 & Rural sprawl / Building Pattern / Fragmentation & Wisconsin, U.S.A. \\
\hline Haase et al. & 2007 & $\begin{array}{l}\text { Hydrology / urban sprawl / Impact on water } \\
\text { balance }\end{array}$ & Leipzig, Germany \\
\hline Hasse et al. & 2003 & $\begin{array}{l}\text { Sprawl / indicator framework / land resource } \\
\text { impact }\end{array}$ & New Jersey, U.S.A. \\
\hline $\mathrm{JRC}$ & 2002 & Urban atlas / database construction / sprawl & Europe \\
\hline Kasanko et al. & 2006 & Sprawl / Indicators / Dispersion of cities & 15 European cities \\
\hline Kline & 2000 & $\begin{array}{l}\text { Growth management / fringe definitions / sprawl } \\
\text { indicators }\end{array}$ & U.S.A. \\
\hline Malpezzi et al. & 2001 & Measuring sprawl / suburbanization / tools & No specific study area \\
\hline Skaburskis & 2006 & New Urbanism / sprawl / suburban & Toronto, Canada \\
\hline Sudhira et al. & 2004 & $\begin{array}{l}\text { Quantifying sprawl / Remote Sensing / spatial } \\
\text { and temporal }\end{array}$ & Mangalore, India \\
\hline Tacoli & 1998 & Sprawl / Rural-urban interactions / definitions & No specific study area \\
\hline Torrens et al. & 2000 & Measuring sprawl / suburbanization / tools & No specific study area \\
\hline Walker et al. & 2008 & Urban Sprawl / Rural landscape / Psychology & Maine, U.S.A. \\
\hline Wolman et al. & 2005 & $\begin{array}{l}\text { Measuring sprawl / condition or process / ex- } \\
\text { tended urban areas }\end{array}$ & $\begin{array}{l}\text { Atlanta, Baltimore, } \\
\text { Boston, LA, Washington, } \\
\text { U.S.A. }\end{array}$ \\
\hline
\end{tabular}


Table 2: Publications using a 'landscape' approach (semi-urban areas).

\begin{tabular}{llll}
\hline Authors & Year & Keywords & Study Area \\
\hline Allen & 2003 & Peri urban interface / semi urban areas definition & No specific study area \\
\hline Antrop & 2004 & Urbanization / suburban landscapes & Europe \\
\hline Antrop et al. & 2000 & $\begin{array}{l}\text { Suburban landscapes / sampling / city expansion } \\
\text { models }\end{array}$ & Ghent, Belgium \\
\hline Barnard et al. & 2001 & Lot size / urban expansion / suburbs & U.S.A. \\
\hline Daniels et al. & 1998 & Suburban fabric / extend countryside / impact & Metropolitan areas, \\
& 1999 & $\begin{array}{l}\text { Contested countryside / clash of functions / edge } \\
\text { cities }\end{array}$ & $\begin{array}{l}\text { Metropolitan areas, } \\
\text { U.S.A. }\end{array}$ \\
\hline Furuseth et al. & 1998 & Suburbanisation & Finland \\
\hline Hiltunen & 1997 & Edge cities / green belts around cities & $\begin{array}{l}\text { Belgium and The Nether- } \\
\text { lands }\end{array}$ \\
\hline Holden et al. & 2000 & $\begin{array}{l}\text { Suburbia / Household level / Energy \& driving } \\
\text { consumption }\end{array}$ & U.S.A. \\
\hline Kahn & 2003 & Rural vs urban camps / linking rural-urban & No specific study area \\
\hline Tacoli & 2001 & $\begin{array}{l}\text { Lack of definitions / exurban development / } \\
\text { mixed land use }\end{array}$ & U.S.A. \\
\hline Theobald & 2005 & Desakota / rural landscapes / urban landscapes & China \\
\hline Xie et al. & &
\end{tabular}


Table 3: Publications mainly focussing on, or using, other concepts, theories and development models related to semi-urban areas.

\begin{tabular}{|c|c|c|c|}
\hline Authors & Year & Keywords & Study Area \\
\hline Adell & 1999 & Review / theories and models / Desakota & No specific study area \\
\hline Alfsen et al. & 2004 & $\begin{array}{l}\text { Megacities / Sustainability management / Bio- } \\
\text { sphere }\end{array}$ & $\begin{array}{l}\text { New York Metropolitan } \\
\text { area, U.S.A. }\end{array}$ \\
\hline Antrop & 2000 & $\begin{array}{l}\text { Patterns / landscape ecology / chronological } \\
\text { framework }\end{array}$ & Flanders, Belgium \\
\hline Bialasiewicz & 2006 & Città Diffusa / social frameworks & Venice, Italy \\
\hline Bourne & 1996 & Suburbs / Exurbia / New Urbanism & No specific study area \\
\hline Bugliarello & 2004 & Knowledge cities, transformation into & New York City, U.S.A. \\
\hline Casaux & 2007 & $\begin{array}{l}\text { Multifunctional agricultrue / agriculture in ur- } \\
\text { ban areas }\end{array}$ & Flanders, Belgium \\
\hline Collins et al. & 2000 & $\begin{array}{l}\text { New urban ecology / integration / multidisci- } \\
\text { plinary }\end{array}$ & No specific study area \\
\hline Daniels et al. & 2005 & Smart growth / exurbia & U.S.A. \\
\hline De Rynck et al. & 2002 & Economische / Sociale / Ecologische principes & Flanders, Belgium \\
\hline Forman & 1995 & Land mosaics / Landscape ecology & No specific study area \\
\hline Gulinck & 2004 & Neo-rurality concept & No specific study area \\
\hline Henderson & 2005 & $\begin{array}{l}\text { Transition farm to urban land use / Poultry } \\
\text { Farmers }\end{array}$ & Australia \\
\hline Henderson & 2003 & $\begin{array}{l}\text { Transition farm to urban land use / Poultry } \\
\text { Farmers }\end{array}$ & $\begin{array}{l}\text { Perth and Sydney, Aus- } \\
\text { tralia }\end{array}$ \\
\hline Katz & 1993 & New Urbanism / small towns & No specific study area \\
\hline Lee et al. & 2003 & New Urbanism vs. Garden City & $\begin{array}{l}\text { Kentlands NJ, Radburn } \\
\text { MD, U.S.A. }\end{array}$ \\
\hline Lynch & 1954 & The form of cities & No specific study area \\
\hline Musacchio et al. & 2004 & Interdisciplinary approaches & $\begin{array}{l}\text { Baltimore, Phoenix, } \\
\text { Willamette Valley, De- } \\
\text { troit, U.S.A. }\end{array}$ \\
\hline Newman & 1999 & Urban ecology / Metabolism concept & No specific study area \\
\hline Pickett et al. & 2004 & Resilient cities / spatial heterogeneity & Baltimore, U.S.A. \\
\hline Potter et al. & 1995 & Social / Economic viewpoints & No specific study area \\
\hline Schrijnen & 2000 & $\begin{array}{l}\text { Infrastructure networks / Red-Green / Grid } \\
\text { Cities }\end{array}$ & No specific study area \\
\hline Talen & 2005 & New urbanism vs. American Planning & U.S.A. \\
\hline Sullivan et al. & 2004 & Conflicts / agricultural buffers / surveys & Illinois, U.S.A. \\
\hline Van Kamp et al. & 2003 & Frameworks / review / multidisciplinary & No specific study area \\
\hline Walmsley & 2006 & $\begin{array}{l}\text { New Urbanism / Greenways / multifunctional } \\
\text { planning }\end{array}$ & New Jersey, U.S.A. \\
\hline Wu et al. & 2002 & Key issues in Landscape ecology & No specific study area \\
\hline Yang et al. & 2007 & Fuzzy boundaries / Urban development & $\begin{array}{l}\text { London, U.K. and Beijing, } \\
\text { China }\end{array}$ \\
\hline Yang et al. & 2004 & $\begin{array}{l}\text { Concept of Industrial Ecology / Nurtured Land- } \\
\text { scapes }\end{array}$ & Singapore \\
\hline Yokohari et al. & 2000 & $\begin{array}{l}\text { Greenbelts / traditional mixed land use / spatial } \\
\text { order }\end{array}$ & Japan \\
\hline
\end{tabular}


Table 4: Publications with their focus on urban (and/or semi-urban) green structures).

\begin{tabular}{|c|c|c|c|}
\hline Authors & Year & Keywords & Study Area \\
\hline Bjerke et al. & 2006 & $\begin{array}{l}\text { Urban parks / vegetation density / residents } \\
\text { preference }\end{array}$ & Trondheim, Norway \\
\hline Chiesura & 2004 & Urban ecology / Parks / Public green & $\begin{array}{l}\text { Amsterdam, The Nether- } \\
\text { lands }\end{array}$ \\
\hline Colding & 2007 & $\begin{array}{l}\text { Ecological land use complementation / gardens / } \\
\text { urban green }\end{array}$ & No specific study area \\
\hline Cook & 2002 & Ecological networks / hydrology & Phoenix, AZ, U.S.A. \\
\hline Cornelis et al. & 2004 & (Sub)urban parks / biodiversity & Flanders, Belgium \\
\hline Gaston et al. & 2005 & Gardens / Urban biodiversity & Sheffield, U.K. \\
\hline Hermy et al. & 2000 & $\begin{array}{l}\text { Parks / Monitoring biodiversity / sub(urban) } \\
\text { Parks }\end{array}$ & Flanders, Belgium \\
\hline Lee et al. & 2008 & $\begin{array}{l}\text { Residents perception / neighborhood satisfaction } \\
\text { / urban green }\end{array}$ & $\begin{array}{l}\text { College Station, TX, } \\
\text { U.S.A. }\end{array}$ \\
\hline Lee et al. & 1997 & Greenbelt planning / Distance dependence & No specific study area \\
\hline Loram et al. & 2007 & Gardens / distance to city / structure & 5 major cities in the U.K. \\
\hline Niemalä & 1999 & Urban nature / urban ecology & No specific study area \\
\hline Pauleit et al. & 2005 & Green structures / Modelling ecological impacts & Merseyside, U.K. \\
\hline Pickett et al. & 2008 & Urban design / plant ecology / suburbs & No specific study area \\
\hline Pickett et al. & 2001 & $\begin{array}{l}\text { Urban ecological ecosystem / interlinking / inte- } \\
\text { grating }\end{array}$ & No specific study area \\
\hline Shaw et al. & 1998 & $\begin{array}{l}\text { Ecological diversity / Parks / Urban green struc- } \\
\text { tures }\end{array}$ & Tucson, AZ, U.S.A. \\
\hline Smith et al. & 2005 & Housing / Land Cover ratios / biodiversity & Sheffield, U.K. \\
\hline Thompson et al. & 2005 & Gardens / Seed Banks / Biodiversity & Sheffield, U.K. \\
\hline Ward-Thompson & 2002 & Parks / Fringe with green as glue / Forman & No specific study area \\
\hline
\end{tabular}


Table 5: Publications focussing on methods and techniques to detect and or measure properties of variables related to semi-urban areas.

\begin{tabular}{|c|c|c|c|}
\hline Authors & Year & Keywords & Study Area \\
\hline Alberti & 2005 & Urban pattern / Ecosystem functions & No specific study area \\
\hline Alig et al. & 2004 & Urbanization figures / econometric & U.S.A. \\
\hline Baker et al. & 2002 & Heat islands / ecological consequences & Phoenix, AZ, U.S.A. \\
\hline Banai & 2005 & Decision support / Analytic Hierarchy Process & No specific study area \\
\hline Böhm & 1998 & Urban structural unit as key tool & No specific study area \\
\hline Bryant & 1995 & Social / Economic viewpoints / local actors & No specific study area \\
\hline Deal et al. & 2004 & Econometric modelling / Land Use Modelling & Illinois, U.S.A. \\
\hline Freeman & 1999 & Site surveying / indicators / ecology & Leeds, U.K. \\
\hline Gober er al. & 2002 & $\begin{array}{l}\text { Construction completion / Annual change of } \\
\text { fringe growth }\end{array}$ & Phoenix, AZ, U.S.A. \\
\hline Haack et al. & 2006 & Urban growth analysis, rural settlements & Kathmandu Valley, Nepal \\
\hline Hagoort et al. & 2002 & $\begin{array}{l}\text { Urbanization patterns / Growth / Cellular au- } \\
\text { tomata }\end{array}$ & $\begin{array}{l}\text { Randstad, The Nether- } \\
\text { lands, Rhein-Ruhr, Ger- } \\
\text { many, Flanders, Belgium }\end{array}$ \\
\hline Heikkila et al. & 2003 & $\begin{array}{l}\text { Mathematical modelling / Desakota / Fuzzy } \\
\text { urban sets }\end{array}$ & China \\
\hline Herold et al. & 2002 & $\begin{array}{l}\text { Spatial analysis / hybrid urban environments / } \\
\text { Fragstats }\end{array}$ & California, U.S.A. \\
\hline Irwin & 2003 & $\begin{array}{l}\text { Exurban areas / land use change modeling / } \\
\text { patterns }\end{array}$ & No specific study area \\
\hline Jenerette et al. & 2007 & Heat islands / rapidly urbanizing ecosystems & Phoenix, AZ, U.S.A. \\
\hline Jensen et al. & 2000 & Implemenation tools / Strategies & Herning, Denmark \\
\hline Jensen et al. & 1999 & Temporal and spatial resolution techniques & No specific study area \\
\hline JRC & 2002 & MOLAND / fragmentation / green edge index & Europe \\
\hline Longley et al. & 2002 & Urban density / space filling & Bristol, U.K. \\
\hline Longley et al. & 1991 & Scale / Shape / Size of urban settlements & Norfolk, U.K. \\
\hline Lopez et al. & 2001 & LU Modelling / Markov Models / LULC change & Morellia city, Mexico \\
\hline Lu et al. & 2004 & $\begin{array}{l}\text { Spectral Mixture Analysis / Urban landscape } \\
\text { analysis }\end{array}$ & Indianapolis, IN, U.S.A. \\
\hline Luck et al. & 2002 & $\begin{array}{l}\text { Gradient analysis / transects / ecological and } \\
\text { landscape metrics }\end{array}$ & Phoenix, AZ, U.S.A. \\
\hline Madhavan et al. & 2001 & Mapping urban land use / Transitions / VIS & Bangkok, Thailand \\
\hline McDonnell et al. & 1997 & Gradient analysis / air pollution / biodiversity & $\begin{array}{l}\text { New York City, Lichtfield } \\
\text { County, NY, U.S.A. }\end{array}$ \\
\hline McDonnell et al. & 1990 & Gradient analysis / Urbanization characteristics & $\begin{array}{l}\text { New York Metropolitan } \\
\text { area, U.S.A. }\end{array}$ \\
\hline Netzband et al. & 1998 & Remote sensing / sealed surfaces / & No specific study area \\
\hline Pauleit et al. & 2000 & Sealed surfaces / Spatial data acquisition / & Munich, Germany \\
\hline Perry et al. & 2008 & $\begin{array}{l}\text { Hydrology / Urban areas / Flooding risk / Im- } \\
\text { pervious surface }\end{array}$ & Leeds, U.K. \\
\hline Saaroni et al. & 2000 & Heat islands & Tel-Aviv, Israel \\
\hline
\end{tabular}


Table 5 - Continued

\begin{tabular}{lcll}
\hline Authors & Year & Keywords & Study Area \\
\hline Stone & 2004 & Impervious surfaces / Regulations & $\begin{array}{l}\text { Madison, Wisconsin, } \\
\text { U.S.A. } \\
\text { Cyphard et al. }\end{array}$ \\
2007 & $\begin{array}{l}\text { Fire risk / Urban-Wildland interface / shrub- } \\
\text { lands }\end{array}$ & $\begin{array}{l}\text { Transect / Gradient analysis / Fragstats / Urban } \\
\text { development }\end{array}$ & $\begin{array}{l}\text { Madison, Wisconsin, } \\
\text { U.S.A. }\end{array}$ \\
\hline Weng & 2007 & The Netherlands \\
\hline White et al. & 2000 & Cellular automata / Land Use Modelling & Shanghai, China \\
\hline Zhang et al. & 2004 & $\begin{array}{l}\text { Gradient analysis / Metropolitan area / } \\
\text { Fragstats }\end{array}$ & \\
\hline
\end{tabular}

Table 6: Publications about general sustainability issues for semi-urban or related areas.

\begin{tabular}{lcll}
\hline Authors & Year & Keywords & Study Area \\
\hline Alfsen-Norodom & 2004 & UNESCO / Biosphere / Sustainability & 11 Cities around the world \\
\hline Balocco et al. & 2004 & Exergy / Urban ecology / Sustainability & Siena, Italy \\
\hline Bugliarello & 2002 & $\begin{array}{l}\text { Ecological Footprinting / Biomass matrix / Sus- } \\
\text { tainability }\end{array}$ & No specific study area \\
\hline Clark & 2003 & Bruntland report / Sustainable city planning & No specific study area \\
\hline Doughty et al. & 2004 & $\begin{array}{l}\text { Ecological footprint analysis of city and urban } \\
\text { area }\end{array}$ & Bath, U.K., \\
\hline Hümmeler & 1998 & Planning instruments / Suburban area & Leipzig, Germany \\
\hline Jarozs & 2008 & $\begin{array}{l}\text { Alternative food networks / Urbanization / Or- } \\
\text { ganic farming }\end{array}$ & $\begin{array}{l}\text { Seattle, Skagit County, } \\
\text { U.S.A. }\end{array}$ \\
\hline McKinney & 2002 & $\begin{array}{l}\text { Biodiversity / habitat dynamics / rural-urban } \\
\text { gradient }\end{array}$ & $\begin{array}{l}\text { London, U.K., Randstad, } \\
\text { The Netherlands }\end{array}$ \\
\hline Muñiz et al. & 2005 & Urban form / Ecological Footprinting & Barcelona, Spain \\
\hline Nuissl et al. & 2008 & Environmental pressures / framework & Belgium, The Nether- \\
& 2006 & lands, Germany, U.K. \\
\hline Pauchard et al. & 1992 & $\begin{array}{l}\text { Ecological footprinting / socio-economical im- } \\
\text { pacts }\end{array}$ & Foncepción, Chile \\
\hline Rees & 2007 & Decision support / Agriculture / Indicators & Finland \\
\hline Yli-Viikari et al. & &
\end{tabular}




\section{References}

Adell, G. (1999), "Theories and models of the peri-urban interface: a changing conceptual landscape (Literature review)", London (Development Planning Unit, University College London). Related online version (cited on 27 November 2008):

http://www.ucl.ac.uk/dpu/pui/research/previous/epm/g_adell.htm. 1, 3.1, 3.3, 3.5, 3.6

Alberti, M. (2005), "The Effects of Urban Patterns on Ecosystem Function", International Regional Science Review, 28(2): 168-192, doi:10.1177/0160017605275160. 4.1, 4.1

Alfsen-Norodom, C. (2004), "Urban Biosphere and Society: Partnership of Cities - Introduction", Annals of the New York Academy of Sciences, 1023: 1-9, doi:10.1196/annals.1319.001. 3.5, 4.1, 4.3

Alfsen-Norodom, C., Boehme, S.E., Clemants, S., Corry, M., Imbruce, V., Lane, B.D., Miller, R.B., Padoch, C., Panero, M., Peters, C.M., Rosenzweig, C., Solecki, W., Walsh, D. (2004), "Managing the Megacity for Global Sustainability: The New York Metropolitan Region as an Urban Biosphere Reserve", Annals of the New York Academy of Sciences, 1023: 125-141, doi: 10.1196/annals.1319.005. 2.3, 3.5, 4.3

Alig, R.J., Kline, J.D., Lichtenstein, M. (2004), "Urbanization on the US Landscape: looking ahead in the 21st century", Landscape and Urban Planning, 69(2-3): 219-234, doi: 10.1016/j.landurbplan.2003.07.004. 4.1

Allen, A. (2003), "Environmental Planning and Management of the Peri-Urban Interface: Perspectives on an Emerging Field", Environment \& Urbanization, 15(1): 135-148, doi: 10.1177/095624780301500103. 3.1, 3.5, 3.5, 3.7

Allen, A., Dávila, J. (2002), "Mind the gap! Bridging the rural-urban divide", id21 insights, 41. URL (cited on 13 November 2008):

http://www.id21.org/insights/insights41/insights-issu01-art00.html. 3.2, 3.5, 3.7

Allen, C.R. (2006), "Sprawl and the Resilience of Humans and Nature: an Introduction to the Special Feature", Ecology and Society, 11(1), 36. URL (cited on 28 November 2008):

http://www. ecologyandsociety.org/vol11/iss1/art36/. 3.4

Allen, S. (2001), "Mat Urbanism: The Thick 2-D", in CASE: Le Corbusier's Venice Hospital and the Mat Building Revival, (Eds.) Sarkis, H., Allard, P., Hyde, T., CASE Series, pp. 118-126, Munich, New York (Harvard Design School / Prestel). 3.7

Angel, S., Sheppard, S.C., Civco, D.L. (2005), "The Dynamics of Global Urban Expansion", Washington, DC (The World Bank). Related online version (cited on 27 November 2008): http://go.worldbank.org/58AOYZVOV0. 1, 4.1

Antrop, M. (2000a), "Background Concepts for Integrated Landscape Analysis", Agriculture, Ecosystems \& Environment, 77(1-2): 17-28, doi:10.1016/S0167-8809(99)00089-4. 5

Antrop, M. (2000b), "Changing Patterns in the Urbanized Countryside of Western Europe", Landscape Ecology, 15(3): 257-270, doi:10.1023/A:1008151109252. 3.1

Antrop, M. (2004), "Landscape Change and the Urbanization Process in Europe", Landscape and Urban Planning, 67(1-4): 9-26, doi:10.1016/S0169-2046(03)00026-4. 1, 3.5, 4.1

Antrop, M., Van Eetvelde, V. (2000), "Holistic Aspects of Suburban Landscapes: Visual Image Interpretation and Landscape Metrics", Landscape and Urban Planning, 50(1-3): 43-58, doi: 10.1016/S0169-2046(00)00079-7. 1, 2.3, 3.1, 3.5, 4.1 
Atkinson, G., Oleson, T. (1996), "Urban Sprawl as a Path Dependent Process", Journal of Economic Issues, 30(2): 609-615. 2.3, 4.1

Bacon, E.N. (1974), Design of Cities, New York (Viking Press), rev. edn. 3.4

Baker, L.A., Brazel, A.J., Selover, N., Martin, C., McIntyre, N., Steiner, F.R., Nelson, A., Musacchio, L. (2002), "Urbanization and Warming of Phoenix (Arizona, USA): Impacts, Feedbacks and Mitigation", Urban Ecosystems, 6(3): 183-203, doi:10.1023/A:1026101528700. 1, 2.2, 2.3, 4.1

Banai, R. (2005), "Land Resource Sustainability for Urban Development: Spatial Decision Support System Prototype", Environmental Management, 36(2): 282-296, doi:10.1007/s00267-004-10470. 4.3

Batty, M., Longley, P. (1997), "The Fractal City", Architectural Design, 67(129): 74-83. 3.4

Batty, M., Longley, P.A. (1987), "Urban Shapes as Fractals", Area, 19(3): 215-221. 3.4

Beauchesne, A., Bryant, C. (1999), "Agriculture and Innovation in the Urban Fringe: the Case of Organic Farming in Quebec, Canada", Tijdschrift voor economische en sociale geografie, 90(3): 320-328, doi:10.1111/1467-9663.00073. 3.3, 3.5, 3.7

Bialasiewicz, L. (2006), "Geographies of production and the contexts of politics: dis-location and new ecologies of fear in the Veneto città diffusa", Environment and Planning D: Society and Space, 24(1): 41-67, doi:10.1068/d346t. 1

Bjerke, T., Østdahl, T., Thrane, C., Strumse, E. (2006), "Vegetation Density of Urban Parks and Perceived Appropriateness for Recreation", Urban Forestry \& Urban Greening, 5(1): 35-44, doi:10.1016/j.ufug.2006.01.006. 4.1

Böhm, P. (1998), "Urban structural units as key indicator for monitoring and optimising the urban environment", in Urban Ecology, (Eds.) Breuste, J., Feldmann, H., Uhlmann, O., Results of the international conference held in Leipzig, Germany, June 25-29, 1997, pp. 442-445, Berlin, Heidelberg (Springer). 2.3, 4.3

Bourne, L.S. (1996), "Reinventing the Suburbs: Old Myths and New Realities", Progress in Planning, 46(3): 163-184, doi:10.1016/0305-9006(96)88868-4. 1, 2.3, 3.4, 3.5, 3.7

Breuste, J., Feldmann, H., Uhlmann, O. (Eds.) (1998), Urban Ecology, Results of the international conference held in Leipzig, Germany, June 25-29, 1997, Berlin, Heidelberg (Springer). 3.7, 4.1

Bronstert, A., Niehoff, D., Bürger, G. (2002), "Effects of Climate and Land-Use Change on Storm Runoff Generation: Present Knowledge and Modelling Capabilities", Hydrological Processes, 16 (2): 509-529, doi:10.1002/hyp.326. 4.1

Bryant, C.R. (1995), "The Role of Local Actors in Transforming the Urban Fringe", Journal of Rural Studies, 11(3): 255-267, doi:10.1016/0743-0167(95)00020-N. 1, 3.3, 3.3, 3.7

Bugliarello, G. (2004a), "Urban Knowledge Parks, Knowledge Cities and Urban Sustainability", International Journal of Technology Management, 28(3-6): 388-394, doi: 10.1504/IJTM.2004.005294. 2.3, 3.5

Bugliarello, G. (2004b), "Urban Sustainability: Science, Technology, and Policies", Journal of Urban Technology, 11(2): 1-11, doi:10.1080/10630730412331297288. 4.1

Living Reviews in Landscape Research

http: //www. livingreviews.org/lrlr-2008-3 
University of Sheffield, "Biodiversity in Urban Gardens projects (BUGS)", project homepage. URL (cited on 28 November 2008):

http://www.bugs.group.shef.ac.uk/. 2.2

Burchell, R.W., Listokin, D., Galley, C.C. (2000), "Smart Growth: More Than a Ghost of Urban Policy Past, Less Than a Bold New Horizon", Housing Policy Debate, 11(4): 821-879. 3.7

Burgess, E.W. (1925), "The Growth of the City: An Introduction to a Research Project", in The City: Suggestions for Investigation of Human Behavior in the Urban Environment, (Eds.) Park, R.E., Burgess, E.W., pp. 47-62, Chicago (University of Chicago Press). Related online version (cited on 28 November 2008):

http://books.google.com/books?id=VjJGyhdMA_sC. 3.4

Cablk, M.E., Minor, T.B. (2003), "Detecting and Discriminating Impervious Cover With High-Resolution IKONOS Data Using Principal Component Analysis and Morphological Operators", International Journal of Remote Sensing, 24(23): 4627-4645, doi: 10.1080/0143116031000102539. 2.3, 4.2

Cadieux, K.V. (2008), "Political ecology of exurban 'lifestyle' landscapes at Christchurch's contested urban fence", Urban Forestry \&3 Urban Greening, 7(3): 183-194, doi: 10.1016/j.ufug.2008.05.003. 1, 4.3

Cain, D.H., Riitters, K., Orvis, K. (1997), "A Multi-Scale Analysis of Landscape Statistics", Landscape Ecology, 12(4): 199-212, doi:10.1023/A:1007938619068. 4.2

Calthorpe, P., Fulton, W. (2001), The Regional City: Planning for the End of Sprawl, Washington, DC (Island Press). 4.1

Carlson, T.N., Arthur, S.T. (2000), "The Impact of Land Use - Land Cover Changes Due to Urbanization on Surface Microclimate and Hydrology: A Satellite Perspective", Global and Planetary Change, 25(1-2): 49-65, doi:10.1016/S0921-8181(00)00021-7. 4.1

Carrión-Flores, C., Irwin, E.G. (2004), "Determinants of Residential Land-Use Conversion and Sprawl at the Rural-Urban Fringe", American Journal of Agricultural Economics, 86(4): 889904, doi:10.1111/j.0002-9092.2004.00641.x. 1, 3.3, 3.4

Casaux, G., Carels, K., Van Gijseghem, D. (2007), "Prospects and challenges for agricultural diversification in a peri-urban region (Flanders - Belgium)", Brussels (Vlaamse Overheid). URL (cited on 13 November 2008):

http://lv.vlaanderen.be/nlapps/docs/default.asp?id=971. 2.3, 3.1, 4.3

Cavailhès, J., Peeters, D., Sékeris, E., Thisse, J.-F. (2004), "The Periurban City: Why to Live Between the Suburbs and the Countryside", Regional Science and Urban Economics, 34(6): 681-703, doi:10.1016/j.regsciurbeco.2003.08.003. 3.1, 3.3, 3.5

Chen, D.M., Stow, D. (2003), "Strategies for Integrating Information From Multiple Spatial Resolutions into Land-Use/Land-Cover Classification Routines", Photogrammetric Engineering 83 Remote Sensing, 69(11): 1279-1287. 4.2

Chiesura, A. (2004), "The Role of Urban Parks for the Sustainable City", Landscape and Urban Planning, 68(1): 129-138, doi:10.1016/j.landurbplan.2003.08.003. 4.1

Colding, J. (2007), “'Ecological land-use complementation' for building resilience in urban ecosystems", Landscape and Urban Planning, 81(1-2): 46-55, doi:10.1016/j.landurbplan.2006.10.016. 4.1 
Collins, J.P., Kinzig, A., Grimm, N.B., Fagan, W.F., Hope, D., Wu, J.G., Borer, E.T. (2000), “A New Urban Ecology", American Scientist, 88(5): 416-425, doi:10.1511/2000.5.416. 3.7

Congress for the New Urbanism (1996), "Charter of the New Urbanism", online resource. URL (cited on 27 November 2008):

http://www. cnu.org/charter. 3.7

Cook, E.A. (2002), "Landscape Structure Indices for Assessing Urban Ecological Networks", Landscape and Urban Planning, 58(2-4): 269-280, doi:10.1016/S0169-2046(01)00226-2. 2.3

Cornelis, J., Hermy, M. (2004), "Biodiversity Relationships in Urban and Suburban Parks in Flanders", Landscape and Urban Planning, 69(4): 385-401, doi:10.1016/j.landurbplan.2003.10.038. $1,4.1$

Countryside Agency Research Programme (2002), "Sustainable Development in the Countryside Around Towns, Vol. 1: Main Report", Manchester (Centre for Urban \& Regional Ecology, University of Manchester). 3.2, 3.4, 3.7, 4.1, 4.3

Daniels, T., Lapping, M. (2005), "Land Preservation: an Essential Ingredient in Smart Growth", Journal of Planning Literature, 19(3): 316-329, doi:10.1177/0885412204271379. 3.7, 4.3

Danielsen, K.A., Lang, R.E., Fulton, W. (1999), "Retracting suburbia: Smart growth and the future of housing", Housing Policy Debate, 10(3): 513-540. 3.7

Davis, C., Schaub, T. (2005), "A Transboundary Study of Urban Sprawl in the Pacific Coast Region of North America: The Benefits of Multiple Measurement Methods", International Journal of Applied Earth Observation and Geoinformation, 7(4): 268-283, doi:10.1016/j.jag.2005.06.007. 4.1

Deal, B., Schunk, D. (2004), "Spatial Dynamic Modeling and Urban Land Use Transformation: A Simulation Approach to Assessing the Costs of Urban Sprawl", Ecological Economics, 51(1-2): 79-95, doi:10.1016/j.ecolecon.2004.04.008. 2.3, 3.3

Doughty, M.R.C., Hammond, G.P. (2004), "Sustainability and the Built Environment at and Beyond the City Scale", Building and Environment, 39(10): 1223-1233. 1, 4.1

Duany, A., Talen, E. (2002), "Transect Planning", Journal of the American Planning Association, 68(3): 245-266, doi:10.1080/01944360208976271. 3.7

Dubois-Taine, G., Chalas, Y. (1997), "La ville émergente", La Tour d'Aigues, France (Éditions de l'Aube). 3.4

Dwyer, J.F., Childs, G.M. (2004), "Movement of people across the landscape: a blurring of distinctions between areas, interests, and issues affecting natural resource management", Landscape and Urban Planning, 69(2-3): 153-164, doi:10.1016/j.landurbplan.2003.09.004. 1, 3.4, 3.5

EEA (2006), "Urban sprawl in Europe: The ignored challenge", EEA Report, 10/2006, Copenhagen (European Environmental Agency). Related online version (cited on 13 November 2008):

http://reports.eea.europa.eu/eea_report_2006_10/. 2.2, 3.4, 4.1

ESPON (2006), "Urban-rural relations in Europe (ESPON 1.1.2. Final Report)", Bengs, C., Schmidt-Thomé, K. (Eds.), Helsinki (Centre for Urban and Regional Studies, Helsinki University of Technology). Related online version (cited on 28 November 2008): http://www . espon.eu/mmp/online/website/content/projects/259/649/index_EN.html. 2.2

Living Reviews in Landscape Research

http://www. livingreviews.org/lrlr-2008-3 
Ewing, R., Pendall, R., Chen, D. (2000), "Measuring Sprawl and Its Transportation Impacts", in Travel Demand and Land Use 2003, pp. 175-183, Washington, DC (Transportation Research Board Natl Research Council). 3.4, 4.1

Felsenstein, D. (2002), "Do high technology agglomerations encourage urban sprawl?", Annals of Regional Science, 36(4): 663-682, doi:10.1007/s001680200101. 2.3, 3.4, 3.5, 4.1

FOD Economie - Algemene Directie Statistiek en Economische Informatie (2008), "Oppervlakte en bevolkingsdichtheid van België", online resource. URL (cited on 13 November 2008): http://statbel.fgov.be/figures/dsp2003_nl.asp. 2.3

Foley, J.A., Defries, R., Asner, G.P., Barford, C., Bonan, G., Carpenter, S.R., Chapin, F.S., Coe, M.T., Daily, G.C., Gibbs, H.K., Helkowski, J.H., Holloway, T., Howard, E.A., Kucharik, C.J., Monfreda, C., Patz, J.A., Prentice, I.C., Ramankutty, N., Snyder, P.K. (2005), "Global Consequences of Land Use", Science, 309(5734): 570-574, doi:10.1126/science.1111772. 4.1

Freeman, C. (1999), "Development of a Simple Method for Site Survey and Assessment in Urban Areas", Landscape and Urban Planning, 44(1): 1-11, doi:10.1016/S0169-2046(98)00114-5. 2.3

Frenkel, A. (2004a), "A Land-Consumption Model: Its Application to Israel's Future Spatial Development", Journal of the American Planning Association, 70(4): 453-470, doi: 10.1080/01944360408976394. 4.1

Frenkel, A. (2004b), "The Potential Effect of National Growth-Management Policy on Urban Sprawl and the Depletion of Open Spaces and Farmland", Land Use Policy, 21(4): 357-369, doi:10.1016/j.landusepol.2003.12.001. 1, 4.1

Friedberger, M. (2000), "The Rural-Urban Fringe in the Late Twentieth Century", Agricultural History, 74(2): 502-514. 3.1

Fulton, W., Pendall, R., Nguyen, M., Harrison, A. (2001), "Who Sprawls Most? How Growth Patterns Differ Across the U.S.", Survey Series, Washington, DC (The Brookings Institution). Related online version (cited on 28 November 2008):

http://www.brookings.edu/es/urban/publications/Fulton.pdf. 1, 3.4, 4.1

Gallent, N., Shoard, M., Andersson, J., Oades, R., Tudor, C. (2004), "England's Urban Fringes: multi-functionality and planning", Local Environment, 9(3): 217-233, doi: 10.1080/1354983042000219342. 1, 3.3, 4.1

Galster, G., Hanson, R., Ratcliffe, M.R., Wolman, H., Coleman, S., Freihage, J. (2001), "Wrestling Sprawl to the Ground: Defining and Measuring an Elusive Concept", Housing Policy Debate, 12(4): 681-717. 1, 3.4, 4.1

Gardner, R.H., O’Neill, R.V., Turner, M.G. (1993), "Ecological Implications of Landscape Fragmentation", in Humans as Components of Ecosystems: The Ecology of Subtle Human Effects and Populated Areas, (Eds.) McDonnell, M.J., Pickett, S.T.A., pp. 208-226, New York (Springer). 4.1

Gaston, K.J., Smith, R.M., Thompson, K., Warren, P.H. (2005a), "Urban domestic gardens (II): experimental tests of methods for increasing biodiversity", Biodiversity and Conservation, 14 (2): 395-413, doi:10.1007/s10531-004-6066-x. 1, 2.2, 2.3, 4.1

Gaston, K.J., Warren, P.H., Thompson, K., Smith, R.M. (2005b), "Urban domestic gardens (IV): the extent of the resource and its associated features", Biodiversity and Conservation, 14(14): 3327-3349, doi:10.1007/s10531-004-9513-9. 4.1 
Gayda, S., Haag, G., Besussi, E., Lautso, K., Noël, C., Martino, A., Moilanen, P., Dormois, R. (2005), "SCATTER: Sprawling Cities And TransporT: from Evalutation to Recommendations (Final Report)", London (Centre for Advanced Spatial Analysis, University College London). Related online version (cited on 28 November 2008):

http://www.casa.ucl.ac.uk/scatter/download_final.html. 2.2

Gillies, R.R., Box, J.B., Symanzik, J., Rodemaker, E.J. (2003), "Effects of Urbanization on the Aquatic Fauna of the Line Creek Watershed, Atlanta - a Satellite Perspective", Remote Sensing of Environment, 86(3): 411-422, doi:10.1016/S0034-4257(03)00082-8. 2.3, 4.1

Gober, P., Burns, E.K. (2002), "The Size and Shape of Phoenix's Urban Fringe", Journal of Planning Education and Research, 21(4): 379-390, doi:10.1177/07356X021004003. 2.3, 3.1, 3.3

Gonzalez-Abraham, C.E., Radeloff, V.C., Hammer, R.B., Hawbaker, T.J., Stewart, S.I., Clayton, M.K. (2007), "Building Patterns and Landscape Fragmentation in Northern Wisconsin, USA", Landscape Ecology, 22(2): 217-230, doi:10.1007/s10980-006-9016-z. 3.1, 4.1

Gulinck, H. (2004), "Neo-rurality and multifunctional landscapes", in Multifunctional Landscapes, Vol. 1: Theory, Values and History, (Eds.) Brandt, J., Vejre, H., vol. 14 of Advances in Ecological Sciences, pp. 63-74, Southampton (WIT Press). 3.1, 3.7, 4.3

Gulinck, H., Wagendorp, T. (2002), "References for Fragmentation Analysis of the Rural Matrix in Cultural Landscapes", Landscape and Urban Planning, 58(2-4): 137-146, doi:10.1016/S01692046(01)00216-X. 2.3, 4.1

Haase, D., Nuissl, H. (2007), "Does Urban Sprawl Drive Changes in the water balance and policy? The case of Leipzig (Germany) 1870-2003", Landscape and Urban Planning, 80(1-2): 1-13, doi:10.1016/j.landurbplan.2006.03.011. 2.3, 4.1

Hackworth, J. (2005), "Emergent Urban Forms, or Emergent Post-Modernisms? A Comparison of Large U.S. Metropolitan Areas", Urban Geography, 26(6): 484-519, doi:10.2747/02723638.26.6.484. 3.7

Hagoort, M., Geertman, S., Ottens, H. (2002), "Urbanization pattern dynamics in the European Delta", in 5th AGILE Conference on GIScience, Proceedings of the conference held in Palma, Spain, 25-27th April 2002, Leuven (AGILE). Related online version (cited on 27 November 2008):

http://plone.itc.nl/agile_old/Conference/mallorca2002/mallorca.html. 1, 3.4, 4.1

Hall, M.J. (1989), Urban Hydrology, New York (Elsevier Science). 4.1

Harris, C.D., Ullman, E.L. (1945), "The Nature of Cities", Annals of the American Academy of Political and Social Science, 242: 7-17, doi:10.1177/000271624524200103. 3.4

Hasse, J.E., Lathrop, R.G. (2003), "Land Resource Impact Indicators of Urban Sprawl", Applied Geography, 23(2-3): 159-175, doi:10.1016/j.apgeog.2003.08.002. 1, 2.3, 4.1, 4.2

Heikkila, E.J., Shen, T.-Y., Yang, K.-Z. (2003), "Fuzzy Urban Sets: Theory and Application to Desakota Regions in China", Environment and Planning B: Planning and Design, 30(2): 239254, doi:10.1068/b12820. 3.6

Hermy, M., Cornelis, J. (2000), "Towards a Monitoring Method and a Number of Multifaceted and Hierarchical Biodiversity Indicators for Urban and Suburban Parks", Landscape and Urban Planning, 49(3-4): 149-162, doi:10.1016/S0169-2046(00)00061-X. 2.3, 4.1

Living Reviews in Landscape Research

http://www. livingreviews.org/lrlr-2008-3 
Herold, M., Scepan, J., Clarke, K.C. (2002), "The use of remote sensing and landscape metrics to describe structures and changes in urban land uses", Environment and Planning A, 34(8): 1443-1458, doi:10.1068/a3496. 4.2

Hite, J. (1998), "Land Use Conflicts on the Urban Fringe: Causes and Potential Resolution", Clemson, SC (Strom Thurmond Institute, Clemson University). URL (cited on 27 November 2008):

http://www.strom.clemson.edu/publications/hite/landuse-hite.pdf. 1, 3.3, 3.3

Hoggan, D.H. (1989), Computer-Assisted Floodplain Hydrology and Hydraulics, New York (McGraw-Hill). 4.1

Holden, R., Turner, T. (1997), "Western Europe, Current City Expansion and the Use of GIS", Landscape and Urban Planning, 36(4): 315-326, doi:10.1016/S0169-2046(96)00362-3. 3.5, 4.1

Hoyt, H. (1939), "The Structure and Growth of Residential Neighbourhoods in American Cities", Washington, DC (Federal Housing Administration). 3.4

Hümmeler, C. (1998), "Strategies for preventing suburbanisation", in Urban Ecology, (Eds.) Breuste, J., Feldmann, H., Uhlmann, O., Results of the international conference held in Leipzig, Germany, June 25-29, 1997, pp. 461-465, Berlin, Heidelberg (Springer). 1, 2.3, 4.3

Irwin, E.G., Bockstael, N.E. (2004), "Land Use Externalities, Open Space Preservation, and Urban Sprawl", Regional Science and Urban Economics, 34(6): 705-725, doi: 10.1016/j.regsciurbeco.2004.03.002. 3.4, 3.5, 3.7

Jarosz, L. (2008), "The City in the Country: Growing Alternative Food Networks in Metropolitan Areas", Journal of Rural Studies, 24(3): 231-244, doi:10.1016/j.jrurstud.2007.10.002. 3.7

Jenerette, G.D., Harlan, S.L., Brazel, A., Jones, N., Larsen, L., Stefanov, W.L. (2007), "Regional Relationships Between Surface Temperature, Vegetation, and Human Settlement in a Rapidly Urbanizing Ecosystem", Landscape Ecology, 22(3): 353-365, doi:10.1007/s10980-006-9032-z. 2.2, $2.3,4.1$

Jennings, D.B., Jarnagin, S.T. (2002), "Changes in Anthropogenic Impervious Surfaces, Precipitation and Daily Streamflow Discharge: A Historical Perspective in a Mid-Atlantic Subwatershed", Landscape Ecology, 17(5): 471-489, doi:10.1023/A:1021211114125. 4.1

Jennings, D.B., Jarnagin, S.T., Ebert, D.W. (2004), "A Modeling Approach for Estimating Watershed Impervious Surface Area From National Land Cover Data 92", Photogrammetric Engineering \& Remote Sensing, 70(11): 1295-1307. 4.1, 4.2

Jensen, J.R., Cowen, D.C. (1999), "Remote Sensing of Urban/Suburban Infrastructure and SocioEconomic Attributes", Photogrammetric Engineering \& Remote Sensing, 65(5): 611-622. 4.2

Jensen, M.B., Persson, B., Guldager, S., Reeh, U., Nilsson, K. (2000), "Green structure and sustainability - developing a tool for local planning", Landscape and Urban Planning, 52(2-3): 117-133, doi:10.1016/S0169-2046(00)00127-4. 4.3

Kahn, M.E. (2000), "The Environmental Impact of Suburbanization", Journal of Policy Analysis and Management, 19(4): 569-586, doi:10.1002/1520-6688(200023)19:4j569::AIDPAM3¿3.0.CO;2-P. 4.1 
Kasanko, M., Barredo, J.I., Lavalle, C., McCormick, N., Demicheli, L., Sagris, V., Brezger, A. (2006), "Are European Cities Becoming Dispersed?: A Comparative Analysis of 15 European Urban Areas", Landscape and Urban Planning, 77(1-2): 111-130, doi: 10.1016/j.landurbplan.2005.02.003. 3.4

Katz, P. (1993), New Urbanism: Toward an Architecture of Community, New York (McGraw-Hill Professional). Related online version (cited on 27 November 2008):

http://books.google.com/books?id=Nb0tNFc5Y90C. 3.7

Kline, J.D. (2000), "Comparing States With and Without Growth Management Analysis Based on Indicators With Policy Implications Comment", Land Use Policy, 17(4): 349-355, doi: 10.1016/S0264-8377(00)00034-X. 3.3, 3.5

Lam, N.S.-N., Quattrochi, D.A. (1992), "On the Issues of Scale, Resolution, and Fractal Analysis in the Mapping Sciences", Professional Geographer, 44(1): 88-98, doi:10.1111/j.00330124.1992.00088.x. 4.2

Lee, C.-M., Ahn, K.-H. (2003), "Is Kentlands Better than Radburn?: The American Garden City and New Urbanist Paradigms", Journal of the American Planning Association, 69(1): 50-71, doi:10.1080/01944360308976293. 3.7

Leinfelder, H. (2007), Dominante en alternatieve planningsdiscoursen ten aanzien van landbouw en open ruimte in een (Vlaamse) verstedelijkende context, Ph.D. Thesis, Universiteit Gent, Gent. $3.2,3.4$

European Union (2007), "Leipzig Charter on Sustainable European Cities", online resource. URL (cited on 28 November 2008):

http://www.eukn.org/eukn/themes/Urban_Policy/leipzig-charter_3334.html. 2.2

Lewis, G.M., Brabec, E. (2005), "Regional Land Pattern Assessment: Development of a Resource Efficiency Measurement Method", Landscape and Urban Planning, 72(4): 281-296, doi: 10.1016/j.landurbplan.2004.03.011. 3.1, 3.4

Libby, L.W., Sharp, J.S. (2003), "Land-Use Compatibility, Change, and Policy at the RuralUrban Fringe: Insights From Social Capital", American Journal of Agricultural Economics, 85 (5): 1194-1200, doi:10.1111/j.0092-5853.2003.00529.x. 3.3

Longley, P.A., Mesev, V. (2002), "Measurement of density gradients and space-filling in urban systems", Papers in Regional Science, 81(1): 1-28, doi:10.1007/s101100100087. 4.2

Loram, A., Tratalos, J., Warren, P.H., Gaston, K.J. (2007), "Urban Domestic Gardens (X): the Extent \& Structure of the Resource in Five Major Cities", Landscape Ecology, 22(4): 601-615, doi:10.1007/s10980-006-9051-9. 4.1

Luck, M., Wu, J.G. (2002), "A Gradient Analysis of Urban Landscape Pattern: a Case Study From the Phoenix Metropolitan Region, Arizona, USA", Landscape Ecology, 17(4): 327-339, doi:10.1023/A:1020512723753. 2.2, 2.3, 3.3, 4.2

Lynch, K. (1954), "The Form of Cities", Scientific American, 190(4): 54-63. 1, 3.4

Madhavan, B.B., Kubo, S., Kurisaki, N., Sivakumar, T.V.L.N. (2001), "Appraising the Anatomy and Spatial Growth of the Bangkok Metropolitan Area Using a Vegetation-Impervious-Soil Model Through Remote Sensing", International Journal of Remote Sensing, 22(5): 789-806, doi:10.1080/01431160051060200. 2.3, 4.1

Living Reviews in Landscape Research

http://www. livingreviews.org/lrlr-2008-3 
Masuda, J.R., Garvin, T. (2008), "Whose Heartland?: The Politics of Place in a Rural-Urban Interface", Journal of Rural Studies, 24(1): 112-123, doi:10.1016/j.jrurstud.2007.08.003. 1

McDonnell, M.J., Pickett, S.T.A. (1990), "Ecosystem Structure and Function Along UrbanRural Gradients: An Unexploited Opportunity for Ecology", Ecology, 71(4): 1232-1237, doi: 10.2307/1938259. 3.4, 4.2

McDonnell, M.J., Pickett, S.T.A., Groffman, P., Bohlen, P., Pouyat, R.V., Zipperer, W.C., Parmelee, R.W., Carreiro, M.M., Medley, K. (1997), "Ecosystem Processes Along an Urbanto-Rural Gradient", Urban Ecosystems, 1(1): 21-36, doi:10.1023/A:1014359024275. 2.2, 2.3, $4.1,4.1,4.2$

McGee, T.G. (1991), "The Emergence of Desakota Regions in Asia: Expanding a Hypothesis", in The Extended Metropolis: Settlement Transition in Asia, (Eds.) Ginsberg, N., Koppel, B., McGee, T.G., Papers from a conference held September 1988 under the auspices of the Environment and Policy Institute of the East-West Center, pp. 3-25, Honolulu (University of Hawaii Press). Related online version (cited on 28 November 2008):

http://books. google.com/books?id=0GWoa3bW-cYC. 3.6

McKinney, M.L. (2002), "Urbanization, Biodiversity, and Conservation", BioScience, 52(10): 883890, doi:10.1641/0006-3568(2002)052[0883:UBAC]2.0.CO;2. 4.1, 4.1, 4.2

McMillen, D.P. (1989), "An Empirical Model of Urban Fringe Land Use", Land Economics, 65(2): 138-145. 2.3, 3.3, 3.3

European Commission / Joint Research Centre, "MOLAND: Monitoring Land Use/Cover Dynamics", project homepage. URL (cited on 13 November 2008):

http://moland.jrc.ec.europa.eu/. 2.2

Mori, H. (1998), "Land Conversion at the Urban Fringe: A Comparative Study of Japan, Britain and the Netherlands", Urban Studies, 35(9): 1541-1558, doi:10.1080/0042098984277. 1, 3.3, 3.4, 4.1

Muñiz, I., Galindo, A. (2005), "Urban Form and the Ecological Footprint of Commuting. The Case of Barcelona", Ecological Economics, 55(4): 499-514, doi:10.1016/j.ecolecon.2004.12.008. 4.1, 4.1

Musacchio, L.R., Wu, J.G. (2004), "Collaborative Landscape-Scale Ecological Research: Emerging Trends in Urban and Regional Ecology", Urban Ecosystems, 7(3): 175-178, doi: 10.1023/B:UECO.0000044034.55695.bd. 1, 2.3

Niehoff, D., Fritsch, U., Bronstert, A. (2002), "Land-Use Impacts on Storm-Runoff Generation: Scenarios of Land-Use Change and Simulation of Hydrological Response in a MesoScale Catchment in SW-Germany", Journal of Hydrology, 267(1-2): 80-93, doi:10.1016/S00221694(02)00142-7. 4.1

Niemelä, J. (1999), "Ecology and Urban Planning", Biodiversity and Conservation, 8(1): 119-131, doi:10.1023/A:1008817325994. 4.1

Nuissl, H., Haase, D., Lanzendorf, M., Wittmer, H. (2009), "Environmental Impact Assessment of Urban Land Use Transitions - A Context-Sensitive Approach", Land Use Policy, 26: 414-424, doi:10.1016/j.landusepol.2008.05.006. 1, 4.1

O’Neill, R.V., Hunsaker, C.T., Timmins, S.P., Jackson, B.L., Jones, K.B., Riitters, K.H., Wickham, J.D. (1996), "Scale Problems in Reporting Landscape Pattern at the Regional Scale", Landscape Ecology, 11(3): 169-180, doi:10.1007/BF02447515. 4.2 
Overbeek, G., Vader, J. (2003), "Urban pressure and rural land use", XX Congress of the European Society for Rural Sociology, 18-22 August 2003, Sligo, Ireland, conference paper. 2.2

Pauchard, A., Aguayo, M., Peña, E., Urrutia, R. (2006), "Multiple Effects of Urbanization on the Biodiversity of Developing Countries: the Case of a Fast-Growing Metropolitan Area (Concepción, Chile)", Biological Conservation, 127(3): 272-281, doi:10.1016/j.biocon.2005.05.015. 1, 4.1

Pauleit, S., Duhme, F. (2000), "Assessing the Environmental Performance of Land Cover Types for Urban Planning", Landscape and Urban Planning, 52(1): 1-20, doi:10.1016/S01692046(00)00109-2. 4.1

Pauleit, S., Ennos, R., Golding, Y. (2005), "Modeling the environmental impacts of urban land use and land cover change - a study in Merseyside, UK", Landscape and Urban Planning, 71 (2-4): 295-310, doi:10.1016/j.landurbplan.2004.03.009. 4.1

Pearce, F. (2006), "Ecopolis now", New Scientist, 190(2556): 36-42. 3.7

Perry, T., Nawaz, R. (2008), "An investigation into the extent and impacts of hard surfacing of domestic gardens in an area of Leeds, United Kingdom", Landscape and Urban Planning, 86(1): 1-13, doi:10.1016/j.landurbplan.2007.12.004. 1, 2.3, 4.1

Pickett, S.T.A., Cadenasso, M.L. (2008), "Linking Ecological and Built Components of Urban Mosaics: An Open Cycle of Ecological Design", Journal of Ecology, 96(1): 8-12, doi:10.1111/j.13652745.2007.01310.x. 1

Pickett, S.T.A., Cadenasso, M.L., Grove, J.M., Nilon, C.H., Pouyat, R.V., Zipperer, W.C., Costanza, R. (2001), "Urban Ecological Systems: Linking Terrestrial Ecological, Physical, and Socioeconomic Components of Metropolitan Areas", Annual Review of Ecology and Systematics, 32: 127-157, doi:10.1146/annurev.ecolsys.32.081501.114012. 4.1, 5

Pickett, S.T.A., Cadenasso, M.L., Grove, J.M. (2004), "Resilient Cities: Meaning, Models, and Metaphor for Integrating the Ecological, Socio-Economic, and Planning Realms", Landscape and Urban Planning, 69(4): 369-384, doi:10.1016/j.landurbplan.2003.10.035. 2.2, 4.3

Plantinga, A.J., Miller, D.J. (2001), "Agricultural Land Values and the Value of Rights to Future Land Development", Land Economics, 77(1): 56-67, doi:10.3368/le.77.1.56. 2.3, 4.1

Platt, R.H. (2004), "Regreening the Metropolis: Pathways to More Ecological Cities", Annals of the New York Academy of Sciences, 1023: 49-61, doi:10.1196/annals.1319.020. 4.1

University of Copenhagen, "PLUREL: Peri-urban Land Use Relationships - Strategies and Sustainability Assessment Tools for Urban-Rural Linkages", project homepage. URL (cited on 28 November 2008):

http://www.plurel.net/. 2.2

Pontius Jr, R.G., Huffaker, D., Denman, K. (2004), "Useful Techniques of Validation for Spatially Explicit Land-Change Models", Ecological Modelling, 179(4): 445-461, doi: 10.1016/j.ecolmodel.2004.05.010. 4.2

Poole, W. (1993), "Preserving Urban and Suburban Gardens and Parks: The Trust for Public Land and Its Partners", in Land Conservation through Public/Private Partnerships, (Ed.) Endicott, E., pp. 61-82, Washington, DC (Island Press). Related online version (cited on 28 November 2008):

http://books.google.com/books?id=rFDTnLS_KCwC. 4.1

Living Reviews in Landscape Research

http://www. livingreviews.org/lrlr-2008-3 
Development Planning Unit, University College London, "Peri-Urban Interface Programme: Strategic Environmental Planning and Management for the Peri-Urban Interface", project homepage. URL (cited on 28 November 2008):

http://www.ucl.ac.uk/dpu/pui/. 2.2

Raymaekers, D., Bauwens, I., Van Orshoven, J., Gulinck, H., Engel, B., Dosselaere, N. (2005), "Spectral unmixing of low resolution images for monitoring soil sealing", in 3rd International Symposium Remote Sensing and Data Fusion Over Urban Areas (URBAN 2005) and 5th International Symposium Remote Sensing of Urban Areas (URS 2005), (Eds.) Moeller, M., Wentz, E., Proceedings of the ISPRS joint conference, March 14-16, 2005, Tempe, AZ, USA, vol. XXXVI of International Archives of Photogrammetry, Remote Sensing and Spatial Information Sciences, Lemmer (ISPRS / GITC). Related online version (cited on 27 November 2008): http://www.isprs.org/commission8/workshop_urban/raymaekers.pdf. 4.2

Rees, W.E. (1992), "Ecological footprints and appropriated carrying capacity: what urban economics leaves out", Environment \& Urbanization, 4(2): 121-130, doi: 10.1177/095624789200400212. 4.1

Rees, W.E. (1999), "The built environment and the ecosphere: a global perspective", Building Research \& Information, 27(4-5): 206-220, doi:10.1080/096132199369336. 3.7

Register, R. (2002), Ecocities: Building Cities in Balance with Nature, Berkeley, CA (Berkeley Hills Books). Related online version (cited on 8 December 2008): http://books . google. com/books? id=nGPBwDgTvAYC. 3.7

Robinson, G.M. (1990), Conflict and change in the countryside: Rural society, economy and planning in the developed world, London; New York (Belhaven Press). 3.2

Ryan, R.L., Hansel Walker, J.T. (2004), "Protecting and Managing Private Farmland and Public Greenways in the Urban Fringe", Landscape and Urban Planning, 68(2-3): 183-198, doi: 10.1016/S0169-2046(03)00165-8. 3.3, 4.1

Saaroni, H., Ben-Dor, E., Bitan, A., Potchter, O. (2000), "Spatial Distribution and Microscale Characteristics of the Urban Heat Island in Tel-Aviv, Israel", Landscape and Urban Planning, 48(1-2): 1-18, doi:10.1016/S0169-2046(99)00075-4. 4.1

Saura, S. (2004), "Effects of Remote Sensor Spatial Resolution and Data Aggregation on Selected Fragmentation Indices", Landscape Ecology, 19(2): 197-209, doi: 10.1023/B:LAND.0000021724.60785.65. 4.2

Savard, J.-P.L., Clergeau, P., Mennechez, G. (2000), "Biodiversity Concepts and Urban Ecosystems", Landscape and Urban Planning, 48(3-4): 131-142, doi:10.1016/S0169-2046(00)00037-2. 4.1, 4.1

Schrijnen, P.M. (2000), "Infrastructure Networks and Red-Green Patterns in City Regions", Landscape and Urban Planning, 48(3-4): 191-204, doi:10.1016/S0169-2046(00)00042-6. 3.4, 4.1

Schuyler, D. (1986), The New Urban Landscape: The Redefinition of City Form in NinetheenthCentury America, Baltimore, MD (John Hopkins University Press). 1

Shannon, K. (2004), Landscape Urbanism, Rhetorics and Realities: Adressing Landscape Urbanism, Three Cities in Vietnam, Ph.D. Thesis, Katholieke Universiteit Leuven, Leuven. 3.7

Shaw, E.M. (1988), Hydrology in Practice, London (Chapman \& Hall), 2nd edn. Related online version (cited on 27 November 2008):

http: //books . google. com/books?id=VXzG9oSFTlsC. 4.1 
Shaw, W.W., Harris, L.K., Livingston, M. (1998), "Vegetative Characteristics of Urban Land Covers in Metropolitan Tucson", Urban Ecosystems, 2(2-3): 65-73, doi:10.1023/A:1009517312486. 1

Skaburskis, A. (2006), "New Urbanism and Sprawl: A Toronto Case Study", Journal of Planning Education and Research, 25(3): 233-248, doi:10.1177/0739456X05278985. 3.7

Smith, R.M., Gaston, K.J., Warren, P.H., Thompson, K. (2005), "Urban domestic gardens (V): relationships between landcover composition, housing and landscape", Landscape Ecology, 20 (2): 235-253, doi:10.1007/s10980-004-3160-0. 2.2, 4.1

Smith, R.M., Thompson, K., Hodgson, J.G., Warren, P.H., Gaston, K.J. (2006), "Urban domestic gardens (IX): Composition and richness of the vascular plant flora, and implications for native biodiversity", Biological Conservation, 129(3): 312-322, doi:10.1016/j.biocon.2005.10.045. 2.3, 4.1

Stone Jr, B. (2004), "Paving Over Paradise: How Land Use Regulations Promote Residential Imperviousness", Landscape and Urban Planning, 69(1): 101-113, doi: 10.1016/j.landurbplan.2003.10.028. 4.1

Sudhira, H.S., Ramachandra, T.V., Jagadish, K.S. (2004), "Urban Sprawl: Metrics, Dynamics and Modelling Using GIS", International Journal of Applied Earth Observation and Geoinformation, 5(1): 29-39, doi:10.1016/j.jag.2003.08.002. 2.3

Sukkop, H., Hejny, S. (Eds.) (1990), Urban Ecology: Plants and Plant Communities in Urban Environments, Papers presented at a symposium held during the 14th International Botanical Congress on 26-27 July 1987, The Hague (SPB Academic Publishing). 4.1

Sullivan, W.C., Anderson, O.M., Lovell, S.T. (2004), "Agricultural Buffers at the RuralUrban Fringe: an Examination of Approval by Farmers, Residents, and Academics in the Midwestern United States", Landscape and Urban Planning, 69(2-3): 299-313, doi: 10.1016/j.landurbplan.2003.10.036. 2.3

Swanson, E. et al. (Development Data Group) (2007), "Urbanization", in World Development Indicators 2007, pp. 162-165, Washington, DC (The World Bank). Related online version (cited on 27 November 2008):

http://go.worldbank.org/8LC3N06N70. 1

Syphard, A.D., Clarke, K.C., Franklin, J. (2007), "Simulating Fire Frequency and Urban Growth in Southern California Coastal Shrublands, USA", Landscape Ecology, 22(3): 431-445, doi: 10.1007/s10980-006-9025-y. 1, 2.3, 4.1

Tacoli, C. (1998a), "Rural-Urban Interactions: A Guide to the Literature", Environment \& Urbanization, 10(1): 147-166, doi:10.1177/095624789801000105. 1, 3.1, 3.5, 3.5

Tacoli, C. (1998b), "Beyond the Rural-Urban Divide", Environment \& Urbanization, 10(1): 3-4, doi:10.1177/095624789801000115. 1, 3.1, 3.7

Tacoli, C. (2003), "The Links Between Urban and Rural Development", Environment Es Urbanization, 15(1): 3-12, doi:10.1177/095624780301500111. 3.2, 3.5, 3.7

Talen, E. (2005), New Urbanism and American Planning: The Conflict of Cultures, New York (Routledge). Related online version (cited on 8 December 2008):

http://books .google.com/books?id=tONATOtz1EUC. 3.7

Living Reviews in Landscape Research

http://www. livingreviews.org/lrlr-2008-3 
The Wye Group Handbook (2007), "Rural Households' Livelihood and Well-Being: Statistics on Rural Development and Agriculture Household Income", New York and Geneva (UNECE / FAO / OECD / The World Bank / EUROSTAT). Related online version (cited on 28 November 2008): http://www.fao.org/statistics/rural/. 3.2

Theobald, D.M. (2001), "Land-Use Dynamics Beyond the American Urban Fringe", Geographical Review, 91(3): 544-564, doi:10.2307/3594740. 1, 3.2, 3.3, 3.5, 4.3

Theobald, D.M. (2004), "Placing Exurban Land-Use Change in a Human Modification Framework", Frontiers in Ecology and the Environment, 2(3): 139-144, doi:10.1890/15409295(2004)002[0139:PELCIA]2.0.CO;2. 4.1

Thompson, K., Austin, K.C., Smith, R.M., Warren, P.H., Angold, P.G., Gaston, K.J. (2003), "Urban Domestic Gardens (I): Putting Small-Scale Plant Diversity in Context", Journal of Vegetation Science, 14(1): 71-78, doi:10.1658/1100-9233(2003)014[0071:UDGIPS]2.0.CO;2. 2.2, 4.1

Thompson, K., Hodgson, J.G., Smith, R.M., Warren, P.H., Gaston, K.J. (2004), "Urban domestic gardens (III): Composition and diversity of lawn floras", Journal of Vegetation Science, 15(3): 373-378. 4.1

Thompson, K., Colsell, S., Carpenter, J., Smith, R.M., Warren, P.H., Gaston, K.J. (2005), "Urban domestic gardens (VII): a preliminary survey of soil seed banks", Seed Science Research, 15(2): 133-141, doi:10.1079/SSR2005201. 2.3, 4.1

Tilt, J.H., Kearney, A.R., Bradley, G. (2007), "Understanding rural character: Cognitive and visual perceptions", Landscape and Urban Planning, 81(1-2): 14-26, doi: 10.1016/j.landurbplan.2006.09.007. 3.2, 3.7

Tischendorf, L., Fahrig, L. (2000), "How Should We Measure Landscape Connectivity?", Landscape Ecology, 15(7): 633-641, doi:10.1023/A:1008177324187. 4.1

Tjallingii, S.P. (1995), Ecopolis: Strategies for Ecologically Sound Urban Development, Leiden (Backhuys Publishers). 3.7

Torrens, P.M., Alberti, M. (2000), "Measuring Sprawl", CASA Working Paper, 27, London (Centre for Advanced Spatial Analysis, University College London). URL (cited on 28 November 2008): http://www.casa.ucl.ac.uk/working_papers/paper27.pdf. 3.4, 4.2

Tress, B., Tress, G. (2003), "Scenario Visualisation for Participatory Landscape Planning - A Study from Denmark", Landscape and Urban Planning, 64(3): 161-178, doi:10.1016/S01692046(02)00219-0. 3.7

Tress, G., Tress, B., Fry, G. (2006), "Publishing Integrative Landscape Research: Analysis of Editorial Policies of Peer-Reviewed Journals", Environmental Science \&3 Policy, 9(5): 466-475, doi:10.1016/j.envsci.2006.03.004. 5

Urban Policy Project (2003), "The Century of the City: City republics and grid cities (White Paper)", De Rynck, F., Boudry, L., Cabus, P., Corijn, E., Kesteloot, C., Loeckx, A. (Eds.), Brussels (Ministry of the Flemish Community). Related online version (cited on 27 November 2008):

http://www.thuisindestad.be/html/witboek/index.html. 3.4

Vogtländer, J.G., Lindeijer, E., Witte, J.-P.M., Hendriks, C. (2004), "Characterizing the change of land-use based on flora: application for EIA and LCA", Journal of Cleaner Production, 12 (1): 47-57, doi:10.1016/S0959-6526(02)00022-7. 4.1 
Waldheim, C. (Ed.) (2006), The Landscape Urbanism Reader, New York (Princeton Architectural Press). Related online version (cited on 8 December 2008):

http://books.google.com/books?id=kqhoMHcYkiAC. 3.7

Walmsley, A. (2006), "Greenways: multiplying and diversifying in the 21st century", Landscape and Urban Planning, 76(1-4): 252-290, doi:10.1016/j.landurbplan.2004.09.036. 2.3, 3.7

Weng, Y.-C. (2007), "Spatiotemporal Changes of Landscape Pattern in Response to Urbanization", Landscape and Urban Planning, 81(4): 341-353, doi:10.1016/j.landurbplan.2007.01.009. 2.3, 4.2

Wilson, A.G. (1976), "Catastrophe Theory and Urban Modelling: An Application to Modal Choice", Environment and Planning A, 8: 351-356, doi:10.1068/a080351. 3.4

Wilson, A.G. (1981), Catastrophe Theory and Bifurcation: Applications to Urban and Regional Systems, London; Berkeley (Croom Helm; University of California Press). 3.4

Wolman, H., Galster, G., Hanson, R., Ratcliffe, M., Furdell, K., Sarzynski, A. (2005), "The Fundamental Challenge in Measuring Sprawl: Which Land Should Be Considered?", Professional Geographer, 57(1): 94-105, doi:10.1111/j.0033-0124.2005.00462.x. 1, 2.3, 3.4, 3.5, 4.2

Wu, C.S., Murray, A.T. (2003), "Estimating impervious surface distribution by spectral mixture analysis", Remote Sensing of Environment, 84(4): 493-505, doi:10.1016/S0034-4257(02)00136-0. 4.2

Wu, J.G. (2004), "Effects of Changing Scale on Landscape Pattern Analysis: Scaling Relations", Landscape Ecology, 19(2): 125-138, doi:10.1023/B:LAND.0000021711.40074.ae. 4.2

Wu, J.G., Hobbs, R. (2002), "Key Issues and Research Priorities in Landscape Ecology: An Idiosyncratic Synthesis", Landscape Ecology, 17(4): 355-365, doi:10.1023/A:1020561630963. 5

Xie, Y., Batty, M., Zhao, K. (2005), "Simulating Emergent Urban Form: Desakota in China", CASA Working Paper, 95, London (Centre for Advanced Spatial Analysis, University College London). URL (cited on 27 November 2008):

http://www.casa.ucl.ac.uk/working_papers/paper95.pdf. 3.6

Yang, P.P.-J., Lay, O.B. (2004), "Applying Ecosystem Concepts to the Planning of Industrial Areas: a Case Study of Singapore's Jurong Island", Journal of Cleaner Production, 12(8-10): 1011-1023, doi:10.1016/j.jclepro.2004.02.028. 2.3, 3.5, 4.3

Yang, T., Hillier, B. (2007), "The fuzzy boundary: the spatial definition of urban areas", in 6th International Space Syntax Symposium, Proceedings of the Symposium, 12 - 15 June 2007, Istanbul, Turkey, Istanbul (Istanbul Technical University). URL (cited on 27 November 2008): http://www.spacesyntaxistanbul.itu.edu.tr/papers.htm. 1, 3.5

Yli-Viikari, A., Hietala-Koivu, R., Huusela-Veistola, E., Hyvönen, T., Perälä, P., Turtola, E. (2007), "Evaluating Agri-Environmental Indicators (AEIs) - Use and Limitations of International Indicators at National Level", Ecological Indicators, 7(1): 150-163, doi: 10.1016/j.ecolind.2005.11.005. 4.3

Yokohari, M., Takeuchi, K., Watanabe, T., Yokota, S. (2000), "Beyond Greenbelts and Zoning: A New Planning Concept for the Environment of Asian Mega-Cities", Landscape and Urban Planning, 47(3-4): 159-171, doi:10.1016/S0169-2046(99)00084-5. 2.3, 3.6, 3.7, 4.1

Yu, X.J., Ng, C.N. (2007), "Spatial and Temporal Dynamics of Urban Sprawl Along Two UrbanRural Transects: A Case Study of Guangzhou, China", Landscape and Urban Planning, 79(1): 96-109, doi:10.1016/j.landurbplan.2006.03.008. 4.2

Living Reviews in Landscape Research

http://www. livingreviews . org/lrlr-2008-3 
Zhang, L.Q., Wu, J.P., Zhen, Y., Shu, J. (2004), "A GIS-based Gradient Analysis of Urban Landscape Pattern of Shanghai Metropolitan Area, China", Landscape and Urban Planning, 69(1): 1-16, doi:10.1016/j.landurbplan.2003.08.006. 2.3, 4.2

Zhao, Y.-G., Zhang, G.-L., Zepp, H., Yang, J.-L. (2007), "Establishing a Spatial Grouping Base for Surface Soil Properties Along Urban-Rural Gradient - A Case Study in Nanjing, China", Catena, 69(1): 74-81, doi:10.1016/j.catena.2006.04.017. 4.2

Zheng, P.Q., Baetz, B.W. (1999), "GIS-Based Analysis of Development Options From a Hydrology Perspective", Journal of Urban Planning and Development, 125(4): 164-180, doi: 10.1061/(ASCE)0733-9488(1999)125:4(164). 4.1

Ziegler, A.D., Giambelluca, T.W., Tran, L.T., Vana, T.T., Nullet, M.A., Fox, J., Vien, T.D., Pinthong, J., Maxwell, J.F., Evett, S. (2004), "Hydrological Consequences of Landscape Fragmentation in Mountainous Northern Vietnam: Evidence of Accelerated Overland Flow Generation", Journal of Hydrology, 287(1-4): 124-146, doi:10.1016/j.jhydrol.2003.09.027. 4.1 